BELLOGY LIBRARE

AUG $\cup, 1995$
Depusitoiy

QDODEREIVED APR 061995

O.S.U. LIBRARIES

\title{
Shorter Contributions to the Stratigraphy and Geochronology of Upper Cretaceous Rocks in the Western Interior of the United States
}

\section{U.S. GEOLOGICAL SURVEY BULLETIN 2113}
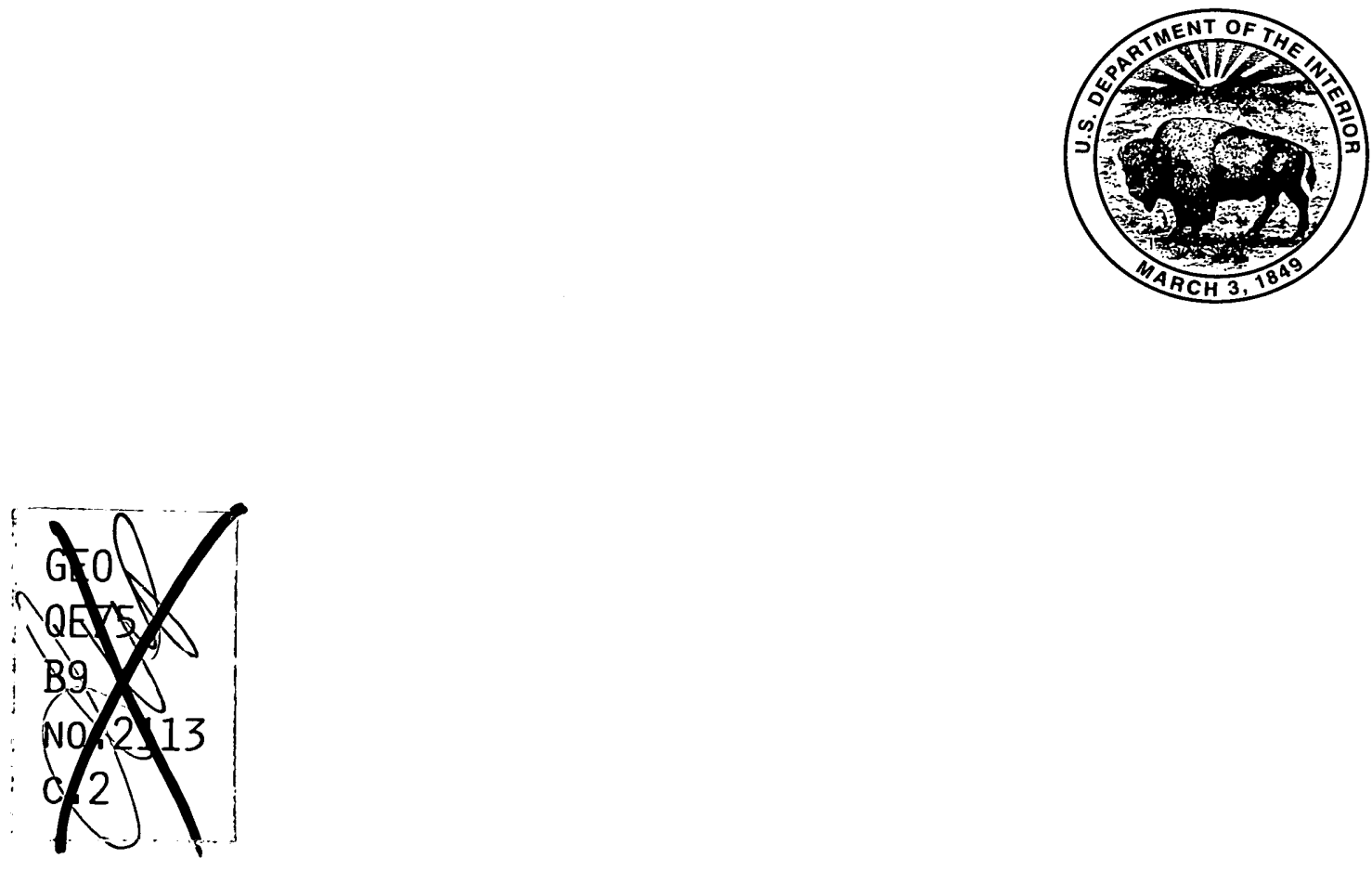
OHIO STATE UNIVERSITY LIBRARIES 


\section{Shorter Contributions to the Stratigraphy and Geochronology of Upper Cretaceous Rocks in the Western Interior of the United States}

A. Conglomerate Facies and Contact Relationships of the Upper Cretaceous Upper Part of the Frontier Formation and Lower Part of the Beaverhead Group, Lima Peaks Area, Southwestern Montana and Southeastern Idaho By T.S. Dyman, J.C. Haley, and W.J. Perry, Jr.

B. U-Pb Ages of Volcanogenic Zircon from Porcellanite Beds in the Vaughn Member of the Mid-Cretaceous Blackleaf Formation, Southwestern Montana By R.E. Zartman, T.S. Dyman, R.G. Tysdal, and R.C. Pearson

C. Occurrences of the Free-Swimming Upper Cretaceous Crinoids Uintacrinus and Marsupites in the Western Interior of the United States By William A. Cobban

U.S. GEOLOGICAL SURVEY BULLETIN 2113

This volume is published as chapters A-C.

These chapters are not available separately

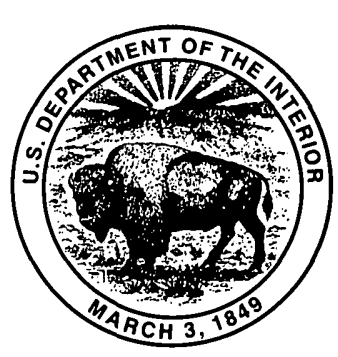

UNITED STATES GOVERNMENT PRINTING OFFICE, WASHINGTON : 1995 


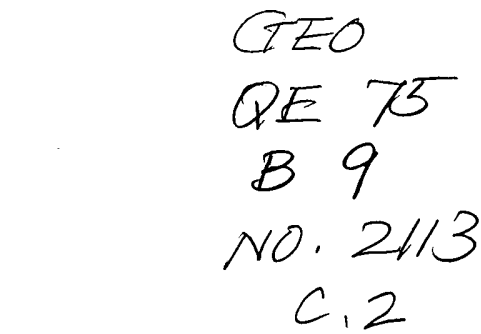

\title{
U.S. DEPARTMENT OF THE INTERIOR BRUCE BABBITT, Secretary
}

\author{
U.S. GEOLOGICAL SURVEY \\ Gordon P. Eaton, Director
}

\author{
Published in the Central Region, Denver, Colorado \\ Manuscript approved for publication August 9, 1994 \\ Edited by Judith Stoeser \\ Graphics by Wayne Hawkins \\ Type composed by Wayne Hawkins
}

For sale by U.S. Geological Survey, Information Services

Box 25286, Federal Center

Denver, CO 80225

\begin{abstract}
Any use of trade, product, or firm names in this publication is for descriptive purposes only and does not imply endorsement by the U.S. Government
\end{abstract}

Library of Congress Cataloging-in-Publication Data

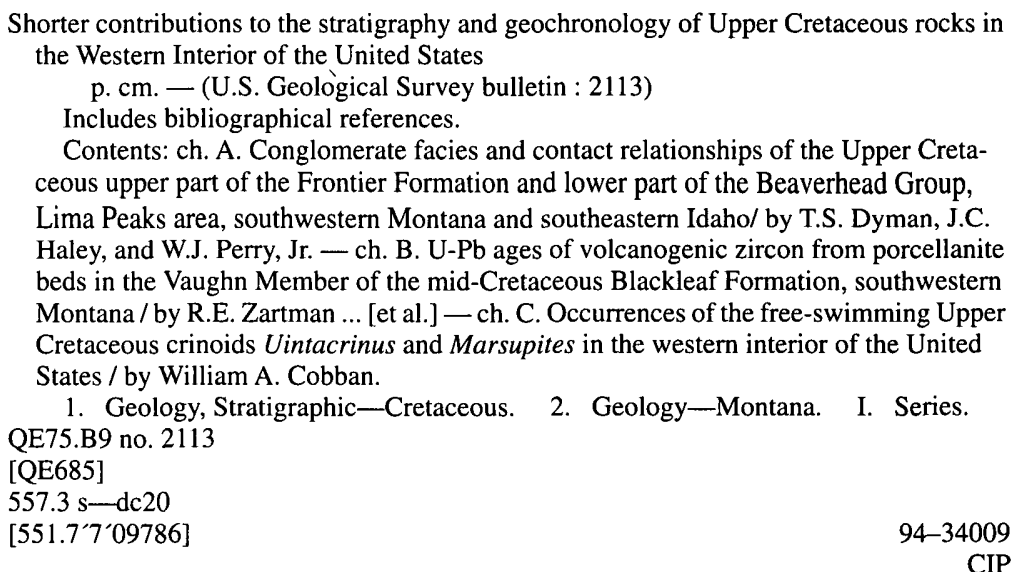




\section{CONTENTS}

A. Conglomerate Facies and Contact Relationships of the Upper Cretaceous Upper Part of the Frontier Formation and Lower Part of the Beaverhead Group, Lima Peaks Area, Southwestern Montana and Southeastern Idaho

By T.S. Dyman, J.C. Haley, and W.J. Perry, Jr.

B. U-Pb Ages of Volcanogenic Zircon from Porcellanite Beds in the Vaughn Member of the Mid-Cretaceous Blackleaf Formation, Southwestern Montana

By R.E. Zartman, T.S. Dyman, R.G. Tysdal, and R.C. Pearson

C. Occurrences of the Free-Swimming Upper Cretaceous Crinoids Uintacrinus and Marsupites in the Western Interior of the United States

By William A. Cobban 


\title{
Conglomerate Facies and Contact Relationships of the
} Upper Cretaceous Upper Part of the Frontier Formation and Lower Part of the Beaverhead Group, Lima Peaks Area, Southwestern Montana and Southeastern Idaho

\author{
By T.S. Dyman, J.C. Haley, and W.J. Perry, Jr.
}

SHORTER CONTRIBUTIONS TO THE STRATIGRAPHY AND GEOCHRONOLOGY OF UPPER CRETACEOUS ROCKS IN THE WESTERN INTERIOR OF THE UNITED STATES

U.S. GEOLOGICAL SURVEY BULLETIN 2113-A

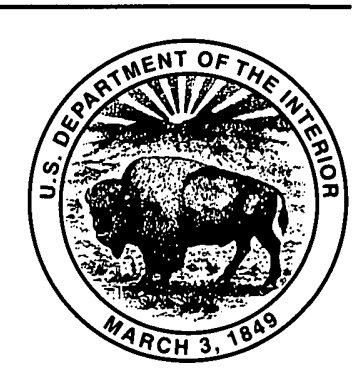




\section{CONTENTS}

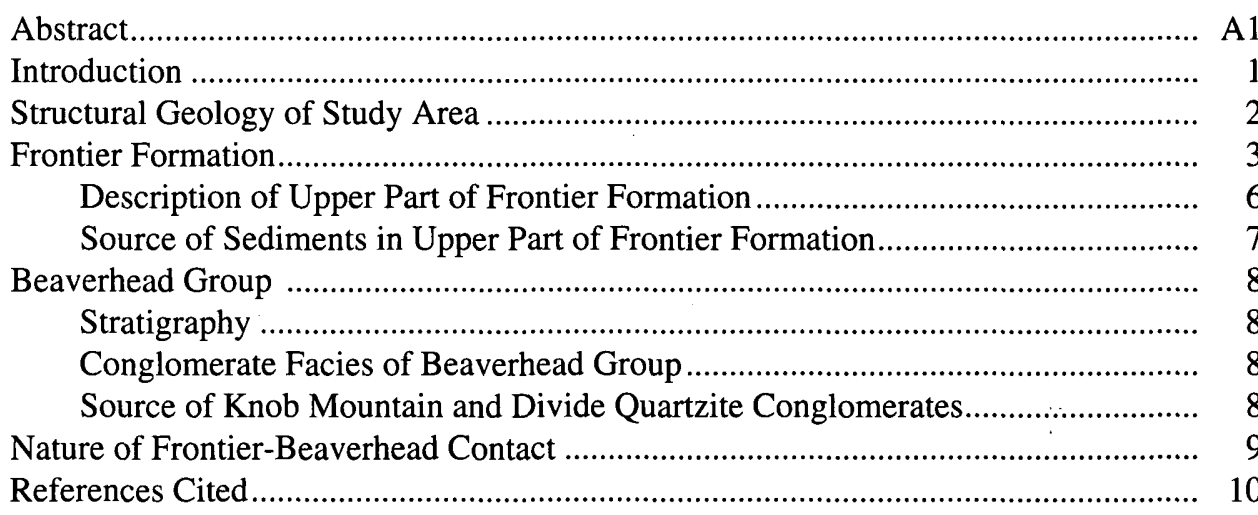

\section{PLATE}

[Plate is in pocket]

1. Measured sections of the Upper Cretaceous upper part of the Frontier Formation and lower part of the Beaverhead Group, Lima Peaks area, southwestern Montana and southeastern Idaho.

\section{FIGURES}

1. Map showing location of measured sections and Frontier Formation-Beaverhead Group contact in study area ....... A2

2. Chart showing stratigraphy of Lower and Upper Cretaceous rocks in study area and surrounding region .................

3. Simplified geologic map of study area

\section{TABLE}

1. Location of measured sections 


\title{
Conglomerate Facies and Contact Relationships of the Upper Cretaceous Upper Part of the Frontier Formation and Lower Part of the Beaverhead Group, Lima Peaks Area, Southwestern Montana and Southeastern Idaho
}

\author{
By T.S. Dyman, J.C. Haley, and W.J. Perry, Jr.
}

\begin{abstract}
The Upper Cretaceous Frontier Formation and overlying Beaverhead Group south of Lima and Monida, Montana, form a thick sequence of nonmarine, predominantly clastic sedimentary rocks deposited in a rapidly subsiding foredeep in front of the Idaho-Montana thrust belt. Five measured sections, each about 3,000 ft (914 m) thick, and detailed mapping of the upper Frontier and lower Beaverhead illustrate that (1) clastic facies vary laterally over the outcrop belt but are present stratigraphically in a predictable manner in each measured section, (2) porcellanite beds persist laterally and are important time and lithostratigraphic markers in the area, and (3) the Frontier-Beaverhead contact changes laterally in the study area and represents a syntectonic unconformity or its conformable equivalent.

Both the Frontier Formation and Beaverhead Group contain intertonguing limestone- and quartzite-clast conglomerate and lithic-rich sandstone that contains abundant limestone fragments. In both units, quartzite-clast conglomerate dominates in the southeastern part of the study area. Quartzite-clast conglomerate is less abundant northwestward and is replaced by limestone-clast conglomerate and associated lithic-rich sandstone. Limestone-clast conglomerate is finer grained and less abundant southeastward; it coarsens upward at each locality, and its composition changes upward from clasts derived from Mesozoic formations in the upper part of the Frontier Formation to clasts derived predominantly from Pennsylvanian through Triassic formations in the overlying Beaverhead Group. Porcellanite and volcaniclastic beds in the upper part of the Frontier Formation aid significantly in correlating the strata, delineating the changing nature of the Frontier-Beaverhead contact, and assembling the facies architecture of the depositional system.
\end{abstract}

The nature of the contact between the Frontier and Beaverhead also changes from northwest to southeast. In the northwest, where limestone-clast conglomerate dominates both units, the Beaverhead overlies the Frontier in profound angular unconformity. To the southeast, where quartzite-clast conglomerate dominates, the sequence is apparently conformable, and the contact is arbitrarily placed at the base of the first coarse conglomerate typical of the Beaverhead Group.

\section{INTRODUCTION}

Our recent work on the Upper Cretaceous strata of southwestern Montana has revealed a series of relationships that we feel are best explained by a syntectonic unconformity within a thick, coarse clastic sequence comprising the upper part of the Frontier Formation and the lower part of the overlying Beaverhead Group. The contact between the Frontier Formation and Beaverhead Group is along an approximately west-northwest to east-southeast trend from the north side of Knob Mountain in Red Conglomerate Peaks to a point approximately $2 \mathrm{mi}(3.2 \mathrm{~km})$ southwest of Humphrey, Idaho, where it is buried by Tertiary and Quaternary gravels and volcanic rocks (fig. 1). At the northwestern end of the outcrop belt, where limestone-clast conglomerate dominates, Frontier and overlying Beaverhead strata meet in angular discordance. At the southeastern end of the outcrop belt, where quartzite-clast conglomerate dominates, no such discordance is apparent.

Our interpretation of a syntectonic unconformity is based not only on mapping formation boundaries and structures but also on (1) detailed mapping of facies within the Frontier Formation and Beaverhead Group, (2) correlated measured sections of the upper Frontier and lower Beaverhead, (3) clast composition of contained conglomerates, and (4) the spatial and temporal context of the Frontier-Beaverhead sequence in the regional tectonic setting. 


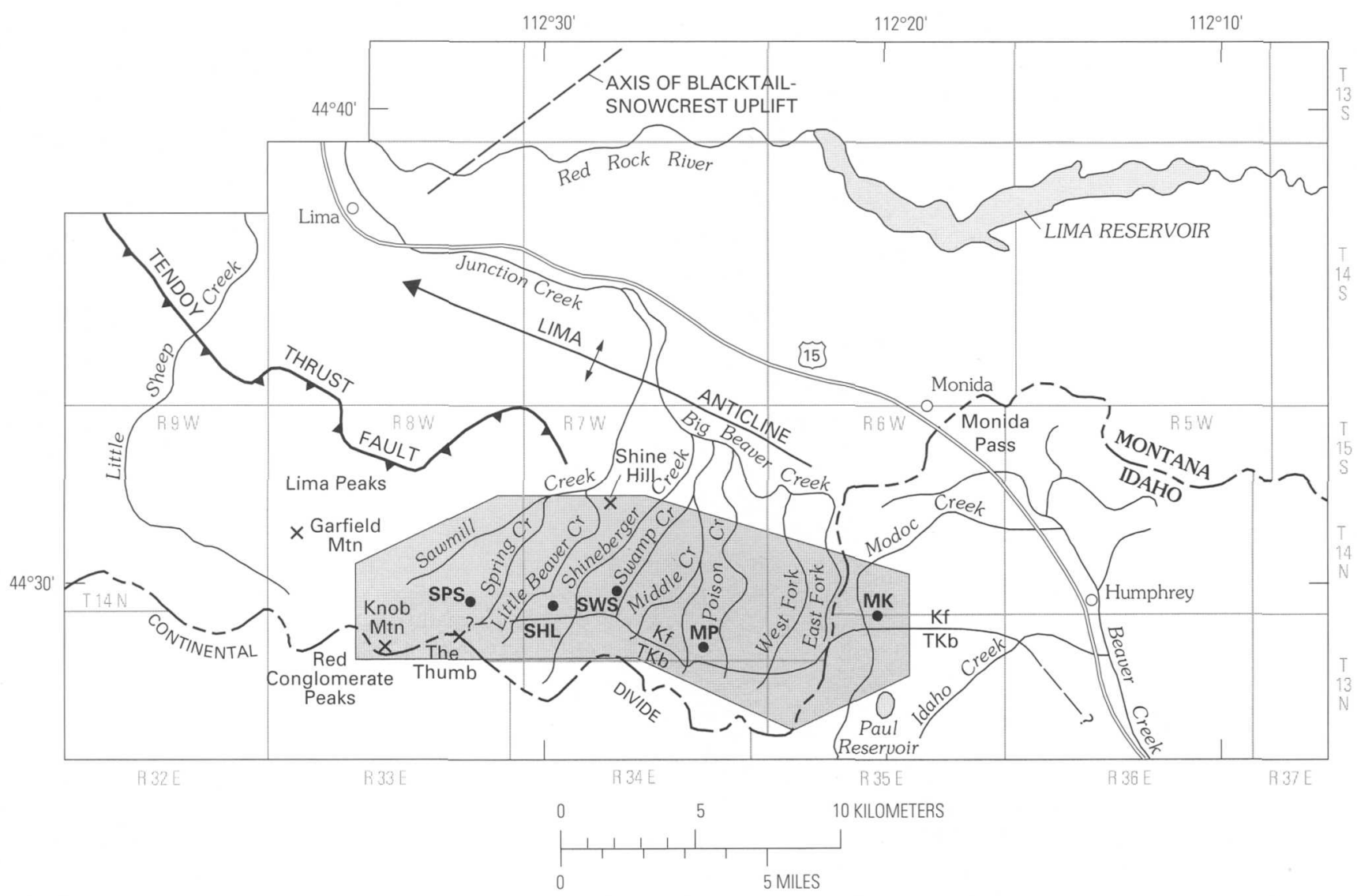

Figure 1. Map showing location of measured sections and the Frontier Formation (Kf)-Beaverhead Group (TKb) contact (dashed and queried where uncertain) in the study area, southwestern Montana and eastern Idaho. Measured sections (plate 1) are indicated by solid circles: SPS, Spring Creek-Sawmill Creek; SHL, Shineberger Creek-Little Beaver Creek; sws, Swamp Creek-Shineberger Creek; MP, Middle Creek-Poison Creek; MK, Modoc Creek-Kettle Creek. Geology of the shaded area is shown in figure 3.

In this paper we present measured sections and lithostratigraphic correlations of the units in order to document a syntectonic unconformity. An understanding of the facies, provenance, and structure of the Frontier Formation is critical to an understanding of the tectonic history of the region.

We wish to acknowledge the careful and thoughtful reviews of Russ Tysdal, U.S. Geological Survey, and Karen Porter, Montana Bureau of Mines and Geology.

\section{STRUCTURAL GEOLOGY OF STUDY AREA}

The study area is in southwestern Beaverhead County, Montana, and adjacent parts of northeastern Idaho, along, and just north of, the Continental Divide between the Red Conglomerate Peaks and the town of Monida, Montana (fig. 1). It is in a region of overlap between the northeast-trending Blacktail-Snowcrest uplift, a Laramide uplift of the Rocky Mountain foreland, and the northwest-trending Idaho-Montana thrust belt (fig. 1) (Scholten and others, 1955; Ryder and Scholten, 1973; Perry and others, 1983; Perry and others,
1988). In order to understand the sedimentary history of the Frontier-Beaverhead beds and the nature of their contact, an explanation of the Late Cretaceous tectonic history of the region is necessary.

The Blacktail-Snowcrest uplift rose during Late Cretaceous time in response to southeastward movement on the Snowcrest-Greenhorn thrust system (Perry and others, 1988). As the uplift rose, it shed and deformed the Lima Conglomerate and associated sandstones of the Beaverhead Group (fig. 2). A well-constrained palynomorph assemblage from near the top of the Lima Conglomerate requires that erosion of the Blacktail-Snowcrest uplift was far advanced, if not complete, by mid-Campanian time (Nichols and others, 1985).

Impinging on the southwest tip of the Blacktail-Snowcrest uplift is a series of northwest-striking thrust faults that brought Mississippian limestones over younger Paleozoic and Mesozoic rocks. The frontalmost exposed thrust fault, the Tendoy, cuts the Lima Conglomerate. Emplacement of the Tendoy thrust sheet to its present position therefore postdated the Campanian and older 


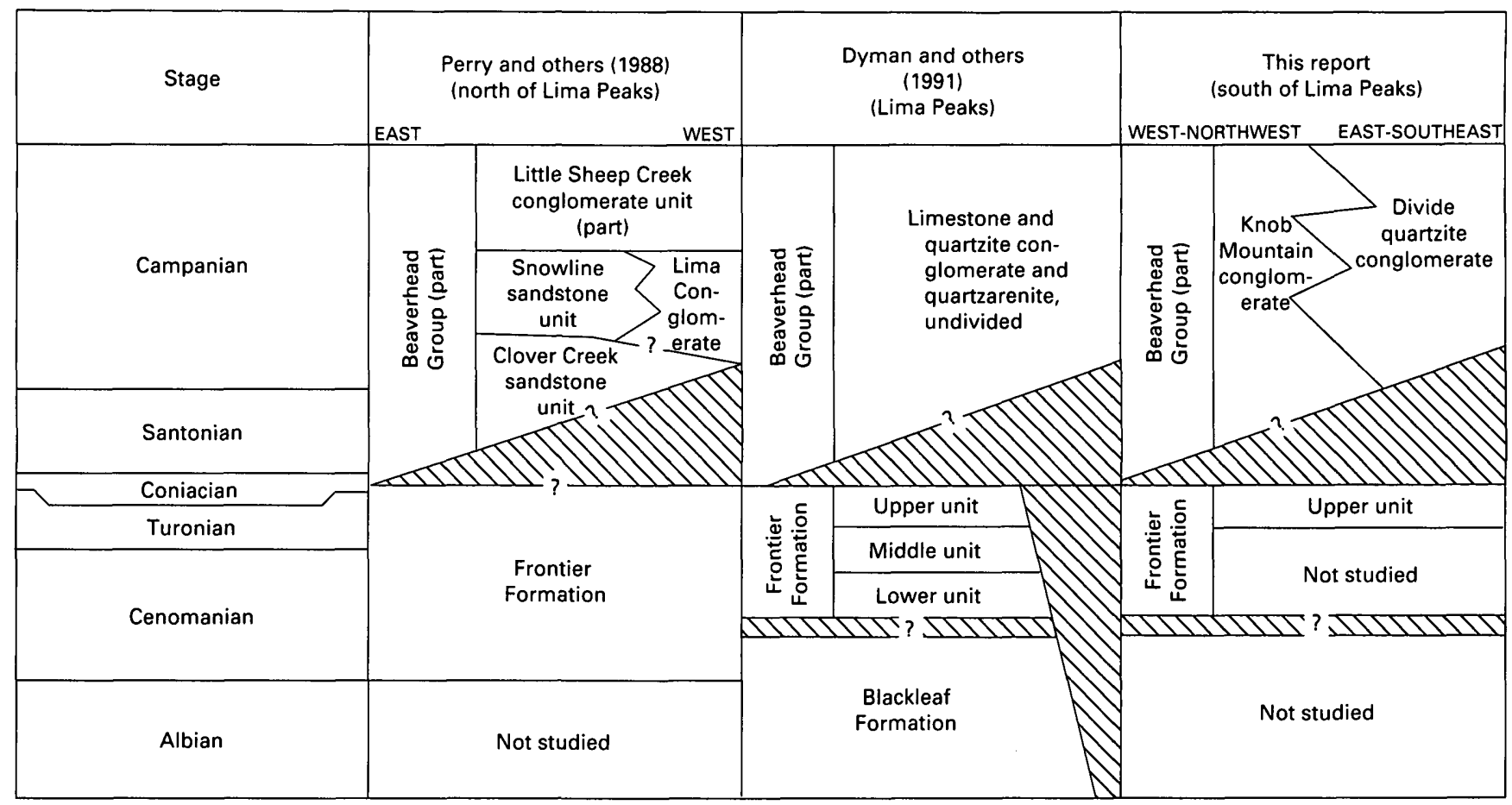

Figure 2. Stratigraphy of Lower and Upper (Albian to Campanian) Cretaceous rocks in the study area and surrounding region. The Clover Creek sandstone unit of Perry and others (1988) is correlative with the Monida sandstone unit of Ryder and Scholten (1.973) and the lower part of the Monida Formation of Wilson (1970) and the Monida Sandstone of Perry and others (1988). The Frontier Formation and Beaverhead Group are disconformable over part of their outcrop area south of Lima and Monida, Montana, but age relationships have not been fully established. The upper part of the Frontier Formation may be Cenomanian or Turonian in age or younger. The sub-Beaverhead unconformity cuts out beds as old as early Mesozoic and late Paleozoic. Cobban and Kennedy (1989) indicated that the Mowry Shale (and equivalent beds including the upper part of the Blackleaf Formation) are all or part Cenomanian in age.

Blacktail-Snowcrest uplift. Haley and Perry (1991) argued for a Maastrichtian to Paleocene age for the Tendoy thrust fault, although they could not rule out an early Eocene minimum age.

A prominent structural feature of the study area is the abrupt change in strike of the Tendoy thrust fault from north-northwest north of the Lima Peaks to east-northeast along the northern margin of the Lima Peaks (fig. 1). Three miles $(5 \mathrm{~km})$ east-northeast of this bend, the hanging wall of the Tendoy thrust fault abruptly cuts upsection from the lower Quadrant Sandstone (Upper Mississippian and Pennsylvanian) through the lower Frontier Formation (Upper Cretaceous). The thrust trace disappears entirely in the Frontier Formation. This change in strike and abrupt termination of the Tendoy fault has been interpreted as (1) a truncation of the southwest nose of the Blacktail-Snowcrest uplift by the Tendoy thrust fault and the resultant formation of a lateral ramp at its southwest end (Perry and others, 1981, 1983), (2) folding of the Tendoy thrust fault and footwall Lima Conglomerate around a late northeast-trending anticline and the resultant tilting on end of the frontal hanging-wall ramp (Haley, 1986), and (3) a combination of both processes (Perry and others, 1988).
The upper part of the Frontier Formation and overlying informal Knob Mountain conglomerate (of Haley, 1986) and Divide quartzite conglomerate (of Ryder, 1972) of the Beaverhead Group (fig. 2) are present in a continuous outcrop belt along the Continental Divide south of the Tendoy thrust fault and eastward beyond the abrupt termination of the Tendoy thrust fault in the Lima Peaks (figs 1,3). Beds of the upper part of the Frontier Formation and the Beaverhead Group strike roughly east to southeast for at least $10 \mathrm{mi}$ (17 $\mathrm{km}$ ) beyond the southeast end of the Tendoy thrust fault (figs. 1, 3). Locally, however, the strike varies due to north-trending, steep to vertical cross faults. Some of these faults are not exposed but were recognized by offset of marker beds, particularly porcellanites, and by changes in structural attitude across the faults. The sense of movement on these faults is uncertain.

\section{FRONTIER FORMATION}

The Frontier Formation, a thick heterogeneous unit of marine and nonmarine sedimentary rocks, is recognized throughout the northern Rocky Mountain region. In Wyoming and Utah, where the most detailed studies of the 


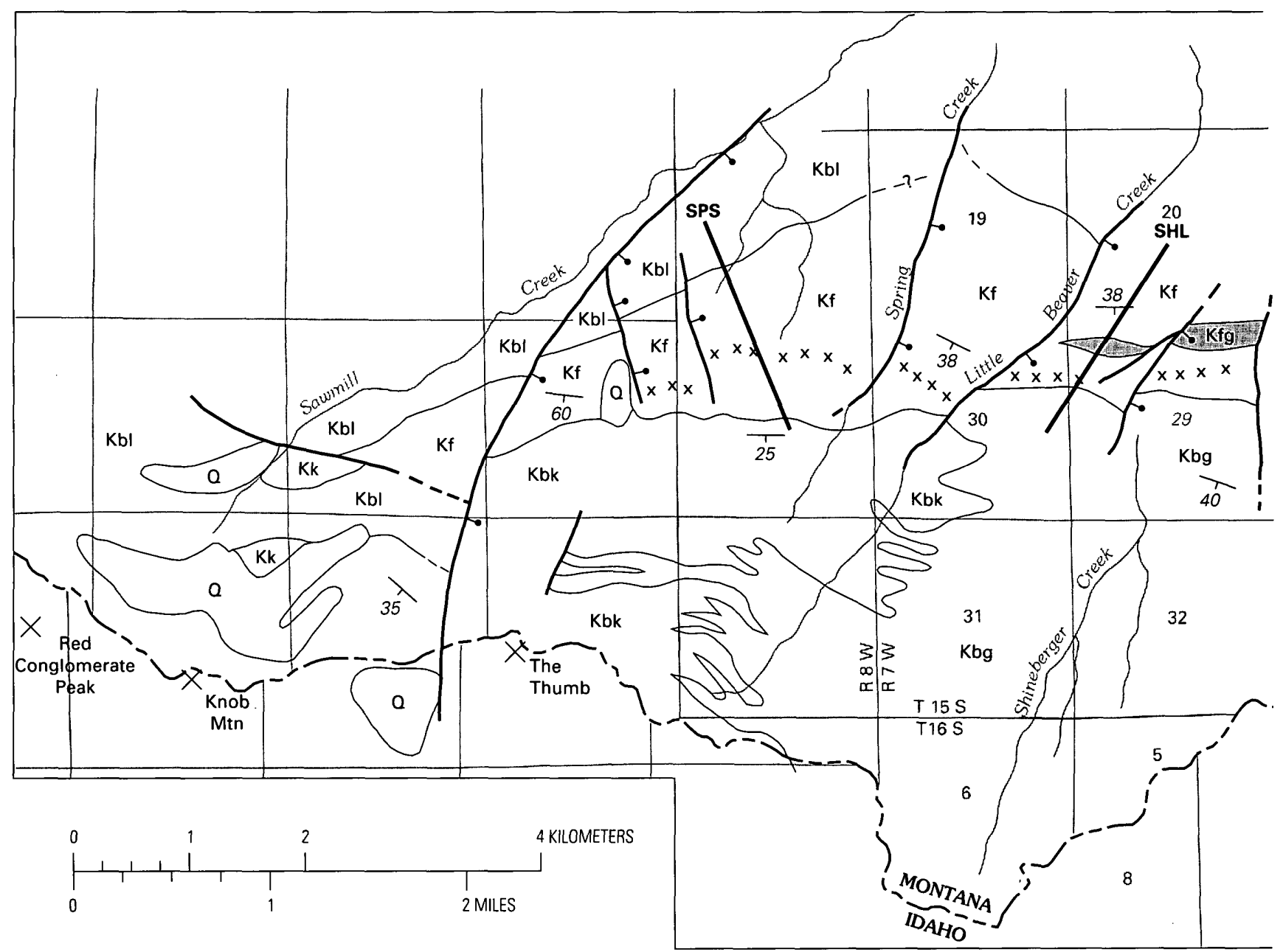

EXPLANATION
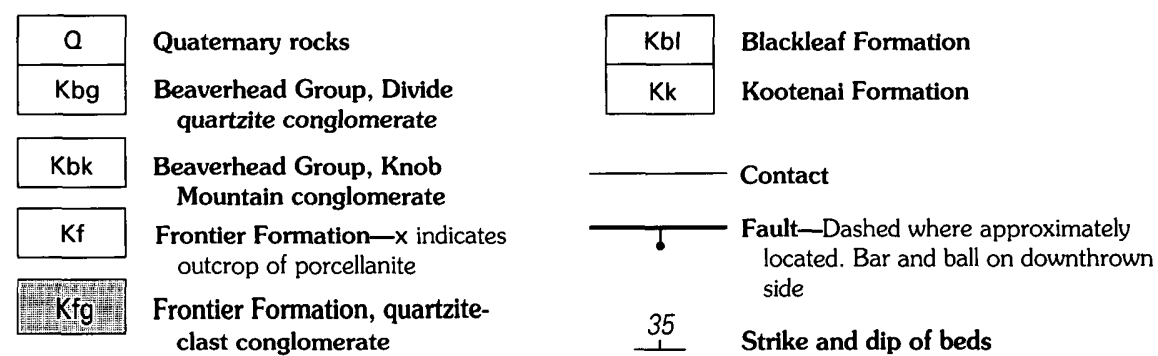

Figure 3. Simplified geologic map of the study area showing formation contacts, major faults, and key beds mapped for this report. Heavy black lines indicate approximate lines along which measured sections (plate 1) were prepared: SPS, Spring Creek-Sawmill Creek; SHL, Shineberger Creek-Little Beaver Creek; swS, Swamp Creek-Shineberger Creek; MP, Middle Creek-Poison Creek; MK, Modoc Creek-Kettle Creek. Location of map area is shown in figure 1.

Frontier Formation have been conducted (see, for example Ryer, 1977), wholly marine sequences in the east grade to intertonguing marine and nonmarine rocks in the west in the Utah-Idaho-Wyoming thrust belt. Generally the thickest sequences are those that have a significant nonmarine depositional component.

In southwest Beaverhead County, Montana, the Frontier Formation is predominantly nonmarine mudstone and siltstone, sandstone, and conglomerate. The lower and upper parts of the formation have a strong volcaniclastic component. The thickness of 7,000+ ft $(2,133+\mathrm{m})$ reported by Dyman and others (1989) for the Frontier in the Lima Peaks area is about the same as that of the westernmost Frontier sections south of the Snake River Plain (Ryer, 1977). In the study area, the Frontier Formation is unconformably underlain by the Lower to Upper Cretaceous Blackleaf Formation, 


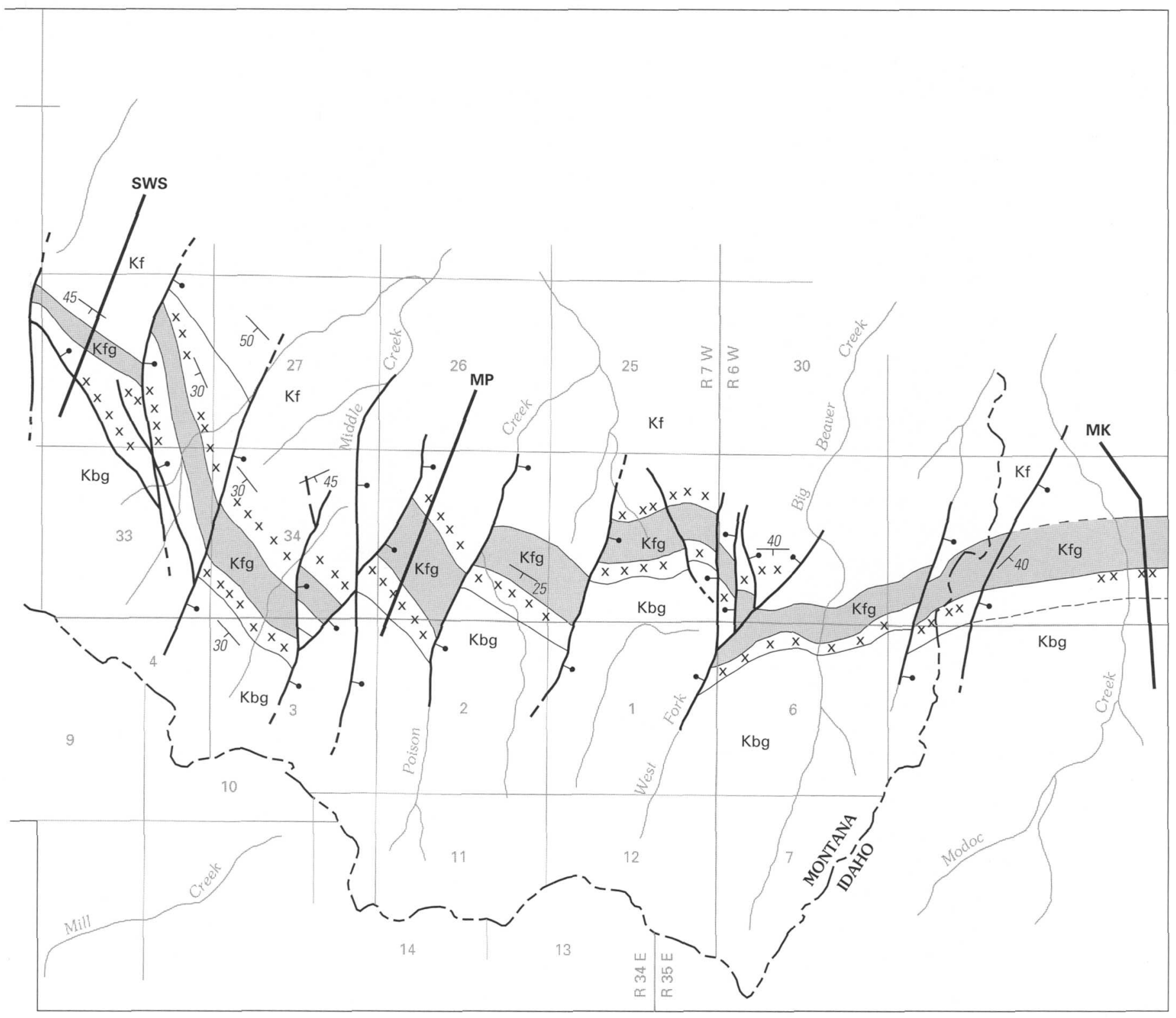

a dominantly nearshore marine coastal, and nonmarine sequence deposited before and at the onset of foreland subsidence (Dyman and Nichols, 1988; Dyman and others, 1989; Tysdal and others, 1989) (fig. 2).

The contact of the Frontier Formation and the overlying Beaverhead Group ranges from conformable to unconformable, depending on location. Near Monida, Montana (fig. 1), the Lima Conglomerate of the Beaverhead Group lies unconformably on the Frontier Formation. Because the Lima Conglomerate was derived from the Blacktail-Snowcrest uplift (Ryder and Scholten, 1973; Nichols and others, 1985; Haley, 1986), the underlying Frontier must have been deposited after strata representing Early to Late Cretaceous foreland basin subsidence and before strata representing Laramide breakup of the foreland.
Clearly, an understanding of the facies, provenance, and structure of the Frontier Formation is critical to an understanding of the tectonic history of the region.

Based on the presence of porcellanite within the stratigraphic section, Dillon (1947) defined all rocks now included in the Frontier and Blackleaf Formations in southern Beaverhead County as Aspen Formation, a name used in western Wyoming and southeastern Idaho for the Albian to Cenomanian Blackleaf equivalent. Reconnaissance studies of Cretaceous rocks in the Lima area led Perry and others (1983) to suggest that Frontier-equivalent rocks were present and that, in light of then recent advances in palynology, the Cretaceous stratigraphy of the area was in need of revision. Nichols and others (1985) reevaluated the palynology of the conglomerate-bearing beds previously dated by Ryder and 
Ames (1970) and determined a Cenomanian to Turonian assemblage for that interval. Concurrent detailed studies of the Blackleaf Formation (Dyman and Nichols, 1988; Dyman and others, 1989) and the Beaverhead Group (Haley, 1986) and unpublished mapping by Perry placed this conglomerate at the base of a thick sequence of undescribed clastic rocks occupying the position between the Blackleaf and Beaverhead. On the basis of its age and its lithologic similarities with nonmarine facies of the Frontier Formation in Wyoming, the sequence was assigned to the Frontier Formation (Perry and others, 1988; Dyman and others, 1989).

Studies of the Frontier (Dyman and others, 1989, 1991) have established the lower and upper contacts and stratigraphy of the formation. Dyman and others (1989) subdivided the Frontier into three informal lithic units: (1) an upper coarse-clastic unit, (2) a middle mudstone-siltstone unit, and (3) a lower coarse-clastic unit. Detailed work on the formation in this region is hampered by very poor exposures, particularly in the lower and middle units. The upper Frontier is the focus of this study and is described following.

\section{DESCRIPTION OF UPPER PART OF FRONTIER FORMATION}

The upper part of the Frontier Formation in the study area is a sequence of conglomerate, lithic and volcaniclastic sandstone, mudstone, siltstone, and minor silty limestone. Mudstone and siltstone are the dominant rock types but are interbedded with laterally discontinuous channellike beds of sandstone and conglomerate. A prominent porcellanite-bearing volcaniclastic interval present throughout the study area permits correlation of the five measured sections (plate 1 , table 1, fig. 3).

The volcaniclastic units are characterized by interbedded porcellanite, crystal tuff, and tuffaceous sandstone. Sedimentary structures include flat and wavy lamination and probable antidune crossbedding. The green to greenish-gray porcellanite is present as dense, aphanitic, siliceous layers that display a conchoidal fracture. The coarser volcaniclastic beds contain abundant subhedral and euhedral zoned plagioclase, potassium feldspar, quartz, and biotite. Tuffaceous sandstone contains clasts of limestone and quartzite as well as volcanic rock fragments.

Conglomerate of the upper Frontier is subdivided into two types, quartzite-clast conglomerate and limestone-clast conglomerate. The quartzite-clast conglomerate is dominated by cobbles and pebbles of well-rounded pink, white, and gray Proterozoic (and possibly lower Paleozoic) quartzite or hard, silica-cemented quartz sandstone. Quartzite clasts typically make up 75-85 percent of the clast composition of a conglomerate bed. Good exposures of quartzite-clast conglomerate are very rare; exposures are in landslide scars or on rounded hills covered in quartzite scree.
Less abundant clasts in the quartzite-clast conglomerate include small cobbles and pebbles of volcanic rocks and chert-armored limestone and dolomite. The volcanic clasts include aphanitic basalt or andesite, intermediate porphyry, and rhyolitic welded tuff. Limestone and dolomite clasts of the quartzite-clast conglomerate commonly contain fragments of brachiopods, crinoids, corals, and bryozoans. Limestone clasts collected from similar conglomerates in the lower part of the Frontier at Shine Hill (fig. 1) contained the conodont Xaniognathus, which is Early Permian in age, and the Middle Pennsylvanian foraminifera Pseudostaffella (Dyman and others, 1989). The clast containing Pseudostaffella may have originated from the Snaky Canyon Formation, which crops out southwest of the study area in central Idaho (B. Skipp, U.S. Geological Survey, written commun., 1989). B. Skipp and W.J. Perry, Jr., identified brown quartzite clasts from the Pennsylvanian to Lower Permian Wood River Formation of central Idaho at Shine Hill. The limestone and dolomite clasts are generally encased in chert that acted as an armor in selectively preserving these clasts during transport. No Mesozoic limestone clasts have been identified in the quartzite-clast conglomerate.

The limestone-clast conglomerate is generally the best exposed of all Frontier rocks. It typically forms discontinuous channel-shaped lenses less than $16 \mathrm{ft}(5 \mathrm{~m})$ thick interbedded with crossbedded quartz- and chert-rich sandstone and pebbly sandstone. Clasts range in size from pebbles to cobbles 6 in. $(20 \mathrm{~cm})$ or more in diameter. Lenses dominated by pebbles are about ten times as abundant as those dominated by cobbles. Cobble-rich lenses of the limestone-clast conglomerate are restricted to the northwestern exposures of the Frontier outcrop belt.

The limestone-clast conglomerate contains as much as 70 percent or more Mesozoic limestone clasts. These clasts are generally light gray, tan, or pink and lack the chert armor of the limestone clasts in the quartzite-clast conglomerate. Notably abundant in the clast assemblage of the limestone-clast conglomerate are pebbles and cobbles of gastropod limestone from the Lower Cretaceous Kootenai Formation and oolitic and fossiliferous limestone from the Middle Jurassic Rierdon Formation (as mapped and described northwest of Lima Peaks by Sadler, 1980). Near the top of the Frontier Formation, in the coarser conglomerate lenses, clasts derived from the Triassic Thaynes and Dinwoody Formations are present.

Chert clasts are second in abundance to limestone clasts in the limestone-clast conglomerate. The amount of chert generally increases as clast diameter decreases, and chert may make up as much as 50 percent of the clasts in the finer pebble-conglomerate lenses. The chert clasts are variable in color, but white, dark gray, black, and tan clasts predominate. These clasts are nearly identical to those in the basal Kootenai Formation. Chert clasts were derived from Paleozoic carbonate rocks or deep-water chert deposits of the 
Table 1. Location of measured sections

[Location of sections shown in figures 1 and 3; measured sections shown on plate 1]

\section{Spring Creek-Sawmill Creek}

From SW1/4 sec. 24 to NE1/4 sec. 25, T. 15 S., R. 8 W., Lima Peaks 7.5-minute quadrangle, Beaverhead County, Montana. Section starts approximately $0.5 \mathrm{mi}(1.8 \mathrm{~km})$ southeast of Sawmill Creek along first ridge west of Spring Creek. Section continues south along hills 7,712 and 7,808 and follows ridge top between Sawmill and Spring Creeks. Top of section at approximately 7,800-foot contour near tree line along ridge crest.

Shineberger Creek-Little Beaver Creek

From SW1/4 sec. 20 to NW1/4 sec. 29 and E1/2 sec. 30, T. 15 S., R. 7 W., Snowline and Edie Ranch 7.5-minute quadrangles, Beaverhead County, Montana, and Clark County, Idaho. Section starts on unnamed hilltop at 7,600-ft contour approximately $0.3 \mathrm{mi}(0.5 \mathrm{~km})$ southwest of hill 7,551 and extends southwest along ridge top between Shineberger and Little Beaver Creeks to approximately 8,000foot contour.

\section{Swamp Creek-Shineberger Creek}

From NE1/4 sec. 21 to W11/2 sec. 28, T. 15 S., R. 7 W., Snowline and Tepee Draw 7.5-minute quadrangles, Beaverhead County, Montana, and Clark County, Idaho. Section starts on northeast flank of hill 7,698 and extends southwest along ridge top between Middle and Poison Creeks to approximately 8,000-foot contour.

Middle Creek-Poison Creek

From $\mathrm{E}^{1 / 2}$ sec. 26 to $\mathrm{W}^{1 / 2} \mathrm{sec}$. 35, T. $15 \mathrm{~S}$., R. 7 W. and NW1/4 sec. 2, T. 16 S., R. 7 W., Snowline and Tepee Draw 7.5-minute quadrangles, Beaverhead County, Montana, and Clark County, Idaho. Section starts on north flank of hill 7,526 and extends southwest along ridge top between Middle and Poison Creeks. Section ends at approximately 7,840-foot contour.

\section{Modoc Creek-Kettle Creek}

From SE1/4 sec. 33, T. 14 N., R. 35 E., south to unsurveyed area immediately west of Modoc Creek, Paul Reservoir 7.5-minute quadrangle, Clark County, Idaho. Section starts on north flank of ridge at approximately 7,280-ft contour and extends south along ridge to about 7,600 -ft contour.

hinterland because the Mesozoic formations contain recycled chert clasts. The relative abundance of Mesozoic limestone detritus at the expense of Paleozoic limestone detritus in the limestone-clast conglomerate is therefore problematic unless the primary source of the pebbles is erosion of basal Cretaceous chert-rich conglomerate beds.

Most conglomerate beds in the upper part of the Frontier Formation are either limestone-clast or quartzite-clast conglomerate. Lenses of conglomerate containing admixed Mesozoic limestone clasts and Proterozoic quartzite clasts are present but relatively rare (see unit descriptions, plate 1).

With the exception of tuffaceous sandstone in the volcaniclastic intervals, sandstone in the upper Frontier is classified as calcareous lithic arenite. Sandstone beds range from a few inches to tens of feet in thickness and are characterized by broad, trough crossbedding and flat, low-angle, and ripple crosslamination. Internal scours floored by pebbles are also abundant. Most of the limestone conglomerate is present as lenses within sandstone intervals. Sandstone composition is quite variable but, in general, reflects the composition of the conglomerate with which the sandstone is associated. Preliminary petrographic data are in Dyman and others (1989). A regional study of sandstone composition trends in the Frontier and its equivalents in Montana is the subject of continuing study by the authors.

Mudstone and siltstone are the most abundant rock types in the upper part of the Frontier Formation, but exposures are rare. Where exposed, these fine-grained rocks are olive green to brown and gray and are highly bentonitic.
They are carbonaceous and a few thin coaly layers are present, although pollen preservation is generally poor. Thin, silty micritic limestone beds punctuate the mudstone-siltstone sequences. The thick covered intervals characteristic of the Frontier in the study area are underlain by fine-grained rocks.

\section{SOURCE OF SEDIMENTS IN UPPER PART OF FRONTIER FORMATION}

The source of upper Frontier Formation conglomerate is currently being studied by the authors. Only a brief discussion of the principal points recognized by studying the measured sections (plate 1) is presented here.

The measured sections shown on plate 1 illustrate some specific trends in the distribution of facies and limestone-clast diameter in a west-northwest to east-southeast direction. Because of limited outcrops, these trends can be analyzed only in this direction. Decrease in maximum clast diameter in the limestone-clast conglomerate and overall percentage of limestone-clast conglomerate in the upper Frontier Formation from west-northwest to east-southeast suggests a west-northwest component to the source area direction. Quartzite clasts and Mesozoic limestone clasts generally are not admixed; their intertonguing in discrete limestone-clast conglomerate and quartzite-clast conglomerate beds suggests that they were derived from different source areas. 
The Lower Cretaceous Kootenai Formation, the Middle and Upper Jurassic Ellis Group, and the Lower Triassic Thaynes and Dinwoody Formations supplied detritus to the limestone-clast conglomerate facies of the upper Frontier.

\section{BEAVERHEAD GROUP STRATIGRAPHY}

The Beaverhead Group contains conglomerate and coarse sandstone and minor mudstone, siltstone, and limestone. These rocks were originally defined as Beaverhead Formation by Lowell and Klepper (1953) and later were mapped in the Lima region by Scholten and others (1955), Wilson (1970), and Ryder and Scholten (1973). Nichols and others (1985) raised the Beaverhead to group status based on the recognition of several mappable genetically significant units (Haley, 1983a, b, 1986). Two units, the Lima Conglomerate, derived from the Blacktail-Snowcrest uplift, and the Red Butte Conglomerate, probably derived from the frontal thrust sheets, have been given formation status (Nichols and others, 1985; Haley and Perry, 1991). Depending on location, rocks of the Beaverhead Group overlie rocks ranging in age from Pennsylvanian through Cretaceous. The lower contact of the Beaverhead is generally unconformable.

Beaverhead conglomerates crop out along the Continental Divide between the Red Conglomerate Peaks and Modoc Creek (figs. 1, 3). They consist of intertonguing limestone-clast and quartzite-clast conglomerate facies but lack the fine-grained lithologies and volcaniclastic rocks of the upper Frontier. Ryder and Scholten (1973) informally termed these the Divide limestone conglomerate and Divide quartzite conglomerate, but they were not assigned formal names when Nichols and others (1985) raised the Beaverhead to group status. Haley (1986) proposed the term "Knob Mountain Formation" for the limestone conglomerates, named for the middle peak in the Red Conglomerate Peaks, but preferred to call the quartzite-clast conglomerates simply "Beaverhead quartzite conglomerates" because their relationship to other quartzite conglomerates in the Beaverhead Group could not be ascertained. A modification of that usage is followed here with the informal term "Knob Mountain conglomerate" for the limestone-clast conglomerate and the informal term "Divide quartzite conglomerate" (after Ryder and Scholten, 1973) for the intertonguing quartzite-clast conglomerate.

\section{CONGLOMERATE FACIES OF BEAVERHEAD GROUP}

The Knob Mountain conglomerate is well exposed along the Continental Divide in the Red Conglomerate Peaks (figs. 1, 3), which literally consist of mountains of limestone-clast conglomerate with peaks exceeding 10,100 $\mathrm{ft}(3,100 \mathrm{~m})$ in elevation. The Knob Mountain conglomerate is at least $1,115 \mathrm{ft}(340 \mathrm{~m})$ thick at Knob Mountain and may be as thick as 4,430 ft (1,350 m) (Ryder and Scholten, 1973).

The Knob Mountain conglomerate is composed of cobble- to boulder-sized limestone-clast conglomerate and interbedded quartz-rich sandstone. Boulders as large as $2 \mathrm{ft}$ $(60 \mathrm{~cm})$ or more are abundant at Knob Mountain, where the conglomerate rests on the Frontier Formation in angular unconformity. Boulders as large as $16 \mathrm{ft}(5 \mathrm{~m})$ or more in diameter are present $1 \mathrm{mi}(1.7 \mathrm{~km})$ northeast of Knob Mountain where the conglomerate rests in angular unconformity on the Jurassic Ellis Group (fig. 1). South of the Spring Creek-Sawmill Creek measured section (figs. 1, 3, plate 1), on the east flank of "The Thumb," coarsest clasts average about $0.5 \mathrm{ft}(30 \mathrm{~cm})$ in diameter. Clasts derived from the Lower and Middle Pennsylvanian Amsden Formation and younger rocks, chiefly the Lower Triassic Dinwoody and Thaynes Formations and the Lower Permian Phosphoria Formation, dominate. Very few Jurassic or younger clasts are present (Haley, 1986) at this location.

Sandstone interbedded with the conglomerate is mostly light gray to white quartzarenite or sublitharenite, reflecting erosion of the Upper Mississippian and Pennsylvanian Quadrant Sandstone. This sandstone is in marked contrast to the salt-and-pepper lithic arenite that characterizes the Frontier (Dyman and others, 1989).

To the south and east of the Red Conglomerate Peaks, the Knob Mountain conglomerate intertongues with the Divide quartzite conglomerate. The Divide quartzite-clast conglomerate closely resembles the quartzite-clast conglomerate of the Frontier but is coarser, commonly containing clasts larger than $0.5 \mathrm{ft}(30 \mathrm{~cm})$.

\section{SOURCE OF KNOB MOUNTAIN AND DIVIDE QUARTZITE CONGLOMERATES}

A detailed analysis of the source of the lower Beaverhead conglomerates is currently being addressed by the authors. Only a brief discussion of the principal points recognized by studying the measured sections is presented here.

The source area for the Divide quartzite conglomerate presumably was west of the study area, probably in thrust-sheet exposures of Precambrian quartzite. Arguments favoring a western thrust-belt source are the same as for the lithologically identical quartzite-clast conglomerates of the Frontier Formation discussed previously.

Two lines of evidence argue strongly for a northern source for the Knob Mountain conglomerate. (1) The angular unconformity beneath the Knob Mountain conglomerate places coarse boulder conglomerate on deformed Jurassic through Cretaceous rocks of the Tendoy thrust sheet. Large boulders of the basal conglomerate are primarily of the Triassic Thaynes Formation and are lithically identical to Thaynes outcrops just a few hundreds of meters to the north. This basal unconformity crosses progressively older rocks 
northward onto the Tendoy thrust sheet. (2) At Knob Mountain, near the Spring Creek-Sawmill Creek measured section (fig. 1), a 1,115-foot-thick (340 m) unbroken section of limestone-clast conglomerate containing no quartzite clasts lies above the unconformity. To the south, west, and southeast, laterally equivalent limestone-clast conglomerate sequences interrupted by beds of quartzite-clast conglomerate at several levels provide evidence for an intertonguing in those directions with other conglomerates from the west.

\section{NATURE OF FRONTIER-BEAVERHEAD CONTACT}

The contact between the upper Frontier Formation and the Beaverhead Group in the Lima Peaks areas of southwestern Montana is along an approximate west to east trend from the north side of Knob Mountain in Red Conglomerate Peaks to a point approximately $2 \mathrm{mi}(3.2 \mathrm{~km})$ southwest of Humphrey, Idaho, where it is buried by Tertiary and Quaternary gravels and volcanic rocks. In a reconnaissance of the area, we confirmed earlier speculations (Ryder and Scholten, 1973) that the nature of this contact changes from west to east (Dyman and others, 1991). From Little Beaver Creek westward, a distinct discordance of bedding exists between the Frontier and overlying Beaverhead strata. This discordance is most pronounced along the ridge separating Swamp Creek and Sawmill Creek (fig. 1, Spring Creek-Sawmill Creek measured section). There, limestone-clast conglomerate beds in the Frontier are vertical and those of the Knob Mountain conglomerate dip south at about $35^{\circ}$.

Eastward from Little Beaver Creek (fig. 1, 3), however, no such discordance between Frontier and Beaverhead strata is apparent. In this area, numerous cross faults form discrete fault blocks of different structural orientation. Within a given fault block, however, orientation of strata across the Frontier-Beaverhead contact is consistent.

The Frontier-Beaverhead contact is nowhere exposed in outcrop, although overlying and underlying discordance is identified by exposures only a few or tens of feet apart. The designation of the contact as either a fault or an angular unconformity is necessarily interpretive. Ryder and Scholten (1973) interpreted the contact as an unconformity. They noted that the contact appeared conformable, or almost so, to the east and suggested "an increasing hiatus at the Beaverhead-Aspen [our Beaverhead-Frontier] unconformity as the Blacktail-Snowcrest arch is approached." Later mappers (Skipp and others, 1976) interpreted the basal Beaverhead contact as a thrust fault where the discordance occurs. Haley (1986) reinterpreted the contact as a lateral transition from conformity to unconformity. He suggested that the mapped contact superficially resembles the Pyrenean-type syntectonic unconformity, but he did not attempt to document this interpretation in detail or discuss its implications.
The following logic led us to conclude that a syntectonic unconformity is present at the Frontier-Beaverhead contact based on the following lines of evidence.

1. One and one-quarter miles $(2 \mathrm{~km})$ west of the northwesternmost measured section (Spring Creek-Sawmill Creek measured section, plate 1), the Knob Mountain conglomerate overlies the Lower Cretaceous Kootenai Formation in an angular unconformity that is exposed in outcrop (Haley, 1986). From that point, the Knob Mountain conglomerate crops out almost continuously, broken only by very small scale faults, eastward to "The Thumb" at the top of the Spring Creek-Sawmill Creek measured section. On the north slope of "The Thumb," angular discordance between Knob Mountain and Frontier strata is evident.

2. The contact between the Frontier and the Divide quartzite conglomerate appears conformable at the eastern end of the study area, not only because of consistent bedding attitude across the contact but also because of rock types. The upper Frontier is characterized by a gradual upward increase in bed thickness, coarseness, and abundance of quartzite-clast conglomerate beds. The overlying Divide quartzite conglomerate is as much as 90 percent quartzite-clast conglomerate. Because of the transitional nature of the rock types, Dyman and others (1991) defined the Frontier-Beaverhead contact in the study area as the top of the uppermost porcellanite interval and considered the contact to be an approximate time line. The first quartzite-clast conglomerate of the Divide quartzite conglomerate lies directly above this contact, and quartzite-clast conglomerate completely dominates the remainder of the stratigraphic section (Spring Creek-Sawmill Creek, Middle Creek-Poison Creek, and Modoc Creek-Kettle Creek measured sections, figs. 1, 3 , plate 1). The Divide quartzite conglomerate intertongues westward with the Knob Mountain conglomerate and is therefore time equivalent to it. Beaverhead strata can be mapped continuously westward to "The Thumb" in the northwestern part of the area (Spring Creek-Sawmill Creek measured section, plate 1) where the transition from Frontier to Knob Mountain strata is similarly characterized by an increase in thickness, coarseness, and abundance of limestone-clast conglomerate.

3. Angular discordance in bedding across the contact is present only where the limestone-clast conglomerate of the uppermost Frontier underlies the Knob Mountain conglomerate. Because syntectonic unconformities are generated by local uplift, and the uplift responsible for this syntectonic unconformity was to the north-northwest, the same unconformity would not be expected to be present south-southeasterly underneath or interbedded with the separately (west to southwesterly) derived quartzite-clast conglomerate. This, in fact, appears to be the case.

4. Bedding attitudes of the limestone-clast conglomerate across the contact are those expected in a syntectonic unconformity generated by uplift to the northwest of the study area. Riba (1976) observed that a syntectonic angular 
unconformity "weakens away from the vergence"; that is, the amount of erosional loss of section in the synorogenic pile decreases away from the uplifted area supplying the detritus and rotating the synorogenic beds. In the study area, the contact shows an attenuation of the angular unconformity from northwest to southeast. Furthermore, Knob Mountain and Frontier strata in the Red Conglomerate Peaks area dip south-southeast, the overlying Knob Mountain beds at a shallower angle than the Frontier. Because all beds are upright, we can infer that the unconformity attenuates to the southeast. This geometry requires uplift to the northwest, the source area of the limestone conglomerate in both units.

\section{REFERENCES CITED}

Cobban, W.A., and Kennedy, W.J., 1989, The ammonite Metengonoceras Hyatt, 1903, from the Mowry Shale (Cretaceous) of Montana and Wyoming: U.S. Geological Survey Bulletin 1787-L, 11 p.

Dillon, E.L., 1947, Stratigraphy of an area near Lima, Beaverhead County, Montana: Urbana, University of Illinois, M.S. thesis, $103 \mathrm{p}$.

Dyman, T.S., Haley, J.C., and Perry, W.J., Jr., 1991, Redefinition of Frontier Formation-Beaverhead Group contact, Lima Peaks area, southwestern Montana and southeastern Idaho, in Contributions to Late Cretaceous stratigraphy and paleontology, western Montana: U.S. Geological Survey Bulletin 1962, p. 1-8.

Dyman, T.S., and Nichols, D.J., 1988, Stratigraphy of the mid-Cretaceous Blackleaf and lower part of the Frontier Formations in parts of Madison and Beaverhead Counties, Montana: U.S. Geological Survey Bulletin 1773, 31 p.

Dyman, T.S., Perry, W.J., Jr., and Nichols, D.J., 1988, Stratigraphy, petrology, and provenance of the Albian Blackleaf Formation and the Cenomanian to Turonian lower part of the Frontier Fomation in part of Beaverhead and Madison Counties, Montana: Mountain Geologist, p. 113-127.

Dyman, T.S., Perry, W.J., Jr., Nichols, D.J., Davis, L.E., and Haley, J.C., 1989, Stratigraphy, petrology, and provenance of the Cenomanian to Turonian Frontier Formation near Lima, southwestern Montana, in French, D.E., and Grabb, R.F., eds., Geologic resources of Montana: Montana Geological Society Field Conference, 1989, Guidebook, p. 103-114.

Haley, J.C., 1983a, Depositional processes in the Beaverhead Formation, southwestern Montana-northeastern Idaho, and their tectonic significance [abs.]: American Association of Petroleum Geologists Bulletin, v. 67, p. 1340.

-1983b, Sedimentology of a synorogenic deposit-The Beaverhead Formation of Montana and Idaho: Geological Society of America Abstracts with Programs, v. 15, p. 589.

1986, Upper Cretaceous (Beaverhead) synorogenic sediments of the Montana-Idaho thrust belt and adjacent foreland-Relationships between sedimentation and tectonism: Baltimore, The John Hopkins University, Ph.D. dissertation, $542 \mathrm{p}$.

Haley, J.C., and Perry, W.J., Jr., 1991, The Red Butte Conglomerate-A thrust-belt-derived conglomerate of the
Beaverhead Group, southwestern Montana: U.S. Geological Survey Bulletin 1945, $19 \mathrm{p}$.

Lowell, W.R., and Klepper, M.R., 1953, Beaverhead Formation, a Laramide deposit in Beaverhead County, Montana: Geological Society of America Bulletin, v. 64, p. 235-244.

Nichols, D.J., Perry, W.J., Jr., and Haley, J.C., 1985, Reinterpretation of the palynology and age of Laramide syntectonic deposits, southwestern Montana and revision of the Beaverhead Group: Geology, v. 13, no. 2, p. 149-153.

Perry, W.J., Jr., Haley, J.C., Nichols, D.J., Hammons, P.M., and Ponton, J.D., 1988, Interactions of Rocky Mountain foreland and Cordilleran thrust belt in Lima region, southwest Montana, in Schmidt, C.J., and Perry, W.J., Jr., eds., Interaction of the Rocky Mountain foreland and the Cordilleran thrust belt: Geological Society of America Memoir 171, p. 267-290.

Perry, W.J., Jr., Ryder, R.T., and Maughan, E.K., 1981, The southern part of the southwest Montana thrust belt, in Tucker, T.E., ed., Southwest Montana: Montana Geological Society Field Conference, 1981, Guidebook, p. 261-273.

Perry, W.J., Jr., Wardlaw, B.R., Bostick, N.H., and Maughan, E.K., 1983, Structure, burial history, and petroleum potential of frontal thrust belt and adjacent foreland, southwest Montana: American Association of Petroleum Geologists Bulletin, v. 67, p. 725-743.

Riba, O., 1976, Syntectonic unconformities of the Alto Cardener, Spanish Pyrenees-A genetic interpretation: Sedimentary Geology, v. 15, p. 213-233.

Ryder, R.T., and Ames, H.T., 1970, Palynology and age of Beaverhead Formation and their paleotectonic implications in Lima region, Montana-Idaho: American Association of Petroleum Geologists Bulletin, v. 54, no. 7, p. 1155-1171.

Ryder, R.T., and Scholten, Robert, 1973, Syntectonic conglomerates in southwestern Montana, their nature, origin, and tectonic significance: Geological Society of America Bulletin, v. 84, p. 773-796.

Ryer, T.A., 1977, Patterns of Cretaceous shallow-marine sedimentation, Coalville and Rockport areas, Utah: Geological Society of America Bulletin, v. 88, p. 177-188.

Sadler, R.K., 1980, Structure and stratigraphy of the Little Sheep Creek area, Beaverhead County, Montana: Corvallis, Oregon State University, M.S. thesis, 289 p.

Scholten, Robert, Keenmon, K.A., and Kupsch, W.O., 1955, Geology of the Lima region, southwestern Montana and adjacent Idaho: Geological Society of America Bulletin, v. 66, p. 345-404.

Skipp, Betty, Prostka, H.J., and Schleicher, D.L., 1976, Preliminary geologic map of the Edie Ranch quadrangle, Clark County, Idaho and Beaverhead County, Montana: U.S. Geological Survey Open-File Report 79-845, scale 1:62,500.

Tysdal, G.G., Dyman, T.S., and Nichols, D.J., 1989, Correlation chart of Lower Cretaceous rocks, Madison Range to Lima Peaks area, southwestern Montana: U.S. Geological Survey Miscellaneous Field Studies Map MF-2067, 16 p.

Wilson, M.D., 1970, Upper Cretaceous-Paleocene synorogenic conglomerates of southwestern Montana: American Association of Petroleum Geologists Bulletin, v. 54, no. 10, p. 1843-1867. 
$\mathrm{U}-\mathrm{Pb}$ Ages of Volcanogenic Zircon from

Porcellanite Beds in the Vaughn Member of the Mid-Cretaceous Blackleaf Formation, Southwestern Montana

By R.E. Zartman, T.S. Dyman, R.G. Tysdal, and R.C. Pearson

SHORTER CONTRIBUTIONS TO THE STRATIGRAPHY AND GEOCHRONOLOGY OF UPPER CRETACEOUS ROCKS IN THE WESTERN INTERIOR OF THE UNITED STATES

U.S. GEOLOGICAL SURVEY BULLETIN 2113-B

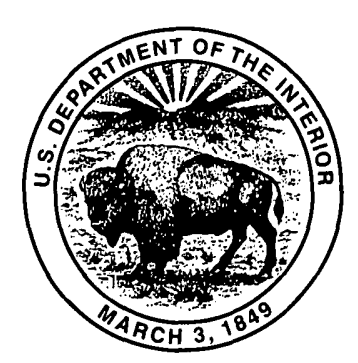

UNITED STATES GOVERNMENT PRINTING OFFICE, WASHINGTON : 1995 


\section{CONTENTS}

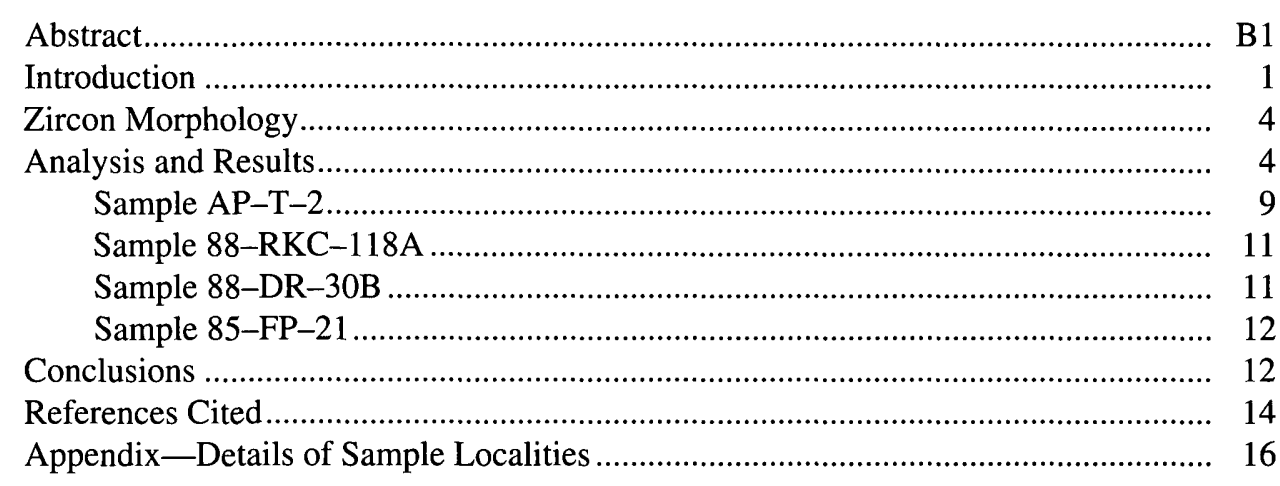

\section{FIGURES}

1. Map of southwestern Montana and adjacent area showing geographic features and sample localities.

2. Simplified stratigraphic chart showing relationship between Vaughn Member and overlying and underlying strata

3. Bar graph showing relative abundances of morphological types of zircon.

4-5. Photomicrographs of $-200+250$ mesh volcanogenic zircon from:

4. Sample 88-RKC-118A showing euhedral morphology of most grains

5. Sample 88-DR-30B showing euhedral morphology of most grains and a markedly uneven development of pyramidal faces.

6. Cumulative plots of length to width ratio (elongation) of zircon from samples in study

7-11. Concordia diagrams:

7. Showing ranges in isotopic composition for all samples................................................................... 10

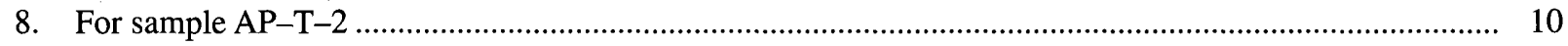

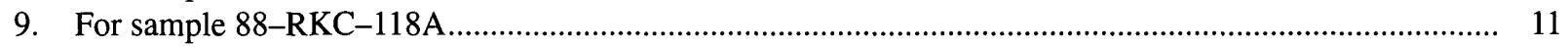

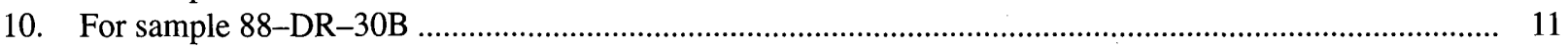

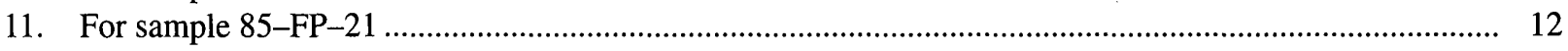

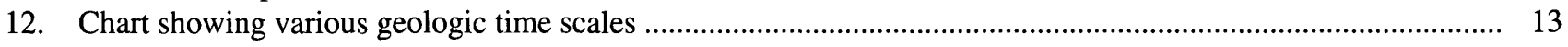

\section{TABLES}

1. Zircon U-Th-Pb isotopic ages of porcellanite beds from the Vaughn Member of the Blackleaf Formation, southwestern Montana .

2. Calibration of mixed ${ }^{205} \mathrm{~Pb}^{235} \mathrm{U}-{ }^{230} \mathrm{Th}$ spike and replicate analyses of standard zircon $\mathrm{S}-2-87$ 


\title{
U-Pb Ages of Volcanogenic Zircon from Porcellanite Beds in the Vaughn Member of the Mid-Cretaceous Blackleaf Formation, Southwestern Montana
}

\author{
By R.E. Zartman, T.S. Dyman, R.G. Tysdal, and R.C. Pearson
}

\begin{abstract}
Zircon is present in sparse amounts $(<1-50 \mathrm{ppm})$ in porcellanitic beds of the upper, volcaniclastic Vaughn Member of the mid-Cretaceous Blackleaf Formation in southwestern Montana. Distinct morphologic varieties of the zircon include colorless to yellow, equant to elongate, euhedral crystals of presumed volcanic origin and pink, rounded grains of detrital origin. Preliminary U-Pb analyses showed that the volcanogenic variety contains older, inherited cores that prevent a precise determination of the time of volcanism. To improve the quality of the geochronologic data, aliquots $(0.1-0.8 \mathrm{mg})$ of zircon, carefully handpicked to emphasize desirable features of the population (crystallinity, elongation, freedom from inclusions and cracks), were chosen for further isotopic measurement. For several samples, complicating phenomena were avoided or minimized by a judicious selection of individual crystals, and essentially concordant ages were obtained.

Highly precise [and accurate] ages were determined for several stratigraphic horizons in the upper part of the Vaughn Member. Porcellanite beds $690 \mathrm{ft}(210 \mathrm{~m})$ and 560 $\mathrm{ft}(170 \mathrm{~m})$ below the top of the Vaughn Member in the eastern Pioneer Mountains and $840 \mathrm{ft}(255 \mathrm{~m})$ below the top of the Vaughn Member near Drummond yielded ages of $96.9 \pm 0.3[ \pm 1.0] \mathrm{Ma}, 96.2 \pm 0.4[ \pm 1.1] \mathrm{Ma}$, and $95.4 \pm 0.4$ [ \pm 1.1$] \mathrm{Ma}$ (precision and [accuracy] uncertainties are $2 \sigma$ ), respectively. A fourth determination, for a bed $80 \mathrm{ft}(25 \mathrm{~m})$ below the top of the Vaughn in the eastern Pioneer Mountains, provided a less precise interpretive age of 95-93 Ma that is consistent with the other results. These data substantiate an early to middle Cenomanian age for the Vaughn Member of the mostly continental Blackleaf Formation, in agreement with biostratigraphic data from presumed equivalent marine rocks to the east.
\end{abstract}

\section{INTRODUCTION}

Age determination of the mid-Cretaceous, mostly nonmarine Blackleaf Formation in southwestern Montana has long been hampered by a paucity of fossils. Our study focuses on the upper part of the youngest member of the formation, the Vaughn Member, between Dillon on the south and Drummond on the north (figs. 1, 2). Although a palynologic assemblage was collected from the Blackleaf Formation farther to the south near Lima, the palynomorphs do not allow assignment to a specific stage of the Cretaceous (Dyman and Nichols, 1988; Dyman and Tysdal, 1991). In order to establish within the Vaughn Member a precise chronostratigraphic unit that can be used to make regional correlations with marine Cretaceous rocks in southwestern and central Montana, these rocks must be dated accurately to $\pm 1 \mathrm{Ma}$ or better. Recent developments in $\mathrm{U}-\mathrm{Th}-\mathrm{Pb}$ isotopic techniques encouraged us to pursue the problem of dating this paleontologically poorly controlled stratigraphic sequence of rocks.

The upper Albian to lower Cenomanian Blackleaf Formation and overlying strata in the Lima Peaks area and eastern Pioneer Mountains were deposited at or near the western margin of the Western Interior seaway as a predominantly nonmarine facies of the Cordilleran foreland basin. The Blackleaf Formation is underlain by the Aptian and Albian(?) Kootenai Formation. In the eastern Pioneer Mountains, overlying strata are unnamed and undivided; they are in part equivalent to the Cenomanian(?) and Turonian Frontier Formation recognized at Lima Peaks and in western Wyoming (Dyman and others, 1989; Tysdal and others, 1989a, 1990). In the Drummond area, overlying strata are referred to the Cenomanian(?) and Turonian Coberly Formation (Gwinn, 1965; Wallace and others, 1986, 1990; Cobban, 1991) (fig. 2). The Blackleaf and overlying strata were deposited farther to the west than their present positions and 


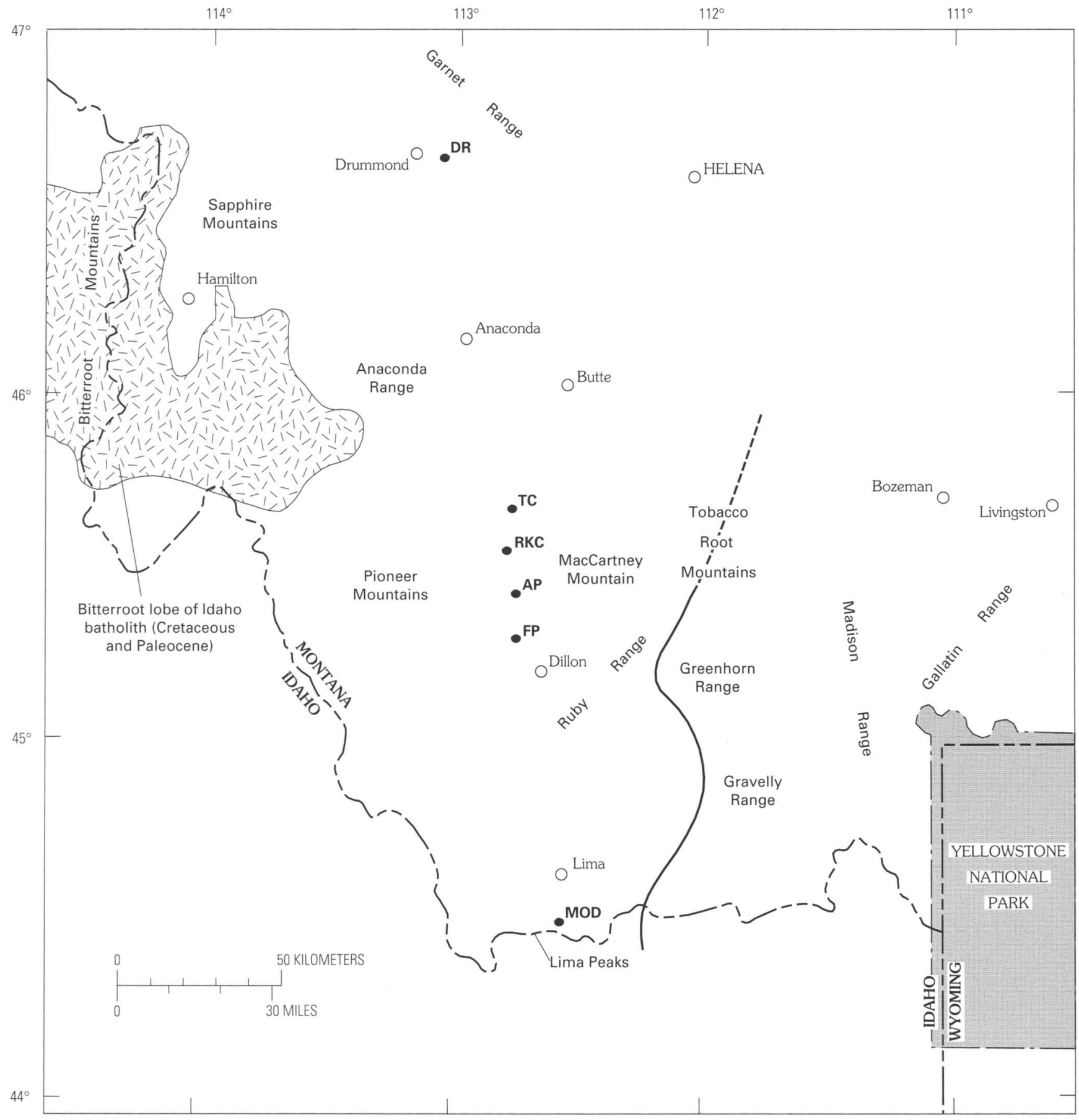

Figure 1. Map of southwestern Montana and adjacent area showing geographic features and sample localities (solid circles). Heavy line denotes approximate position of shoreline during deposition of Blackleaf Formation and equivalent units. It also denotes boundary defining stratigraphic nomenclature, whereby Blackleaf Formation is used west of the line and Thermopolis Shale, Muddy Sandstone, and Mowry Shale is used east of the line. Details of sample localities are given in the appendix.

were moved to their present position by thrust faulting of Late Cretaceous and Tertiary age.

The Blackleaf Formation in the Lima Peaks area and eastern Pioneer Mountains is subdivided into the siliciclastic- and shale-rich Flood Member and the overlying siliciclastic and volcaniclastic Vaughn Member. The Flood Member is a mixed clastic sequence of quartz- and lithic-rich sandstone, mudstone, siltstone, and dark-gray shale; it ranges in thickness from $495 \mathrm{ft}(150 \mathrm{~m})$ at Lima Peaks to $1,270 \mathrm{ft}(387 \mathrm{~m})$ at Rock Creek in the eastern Pioneer 


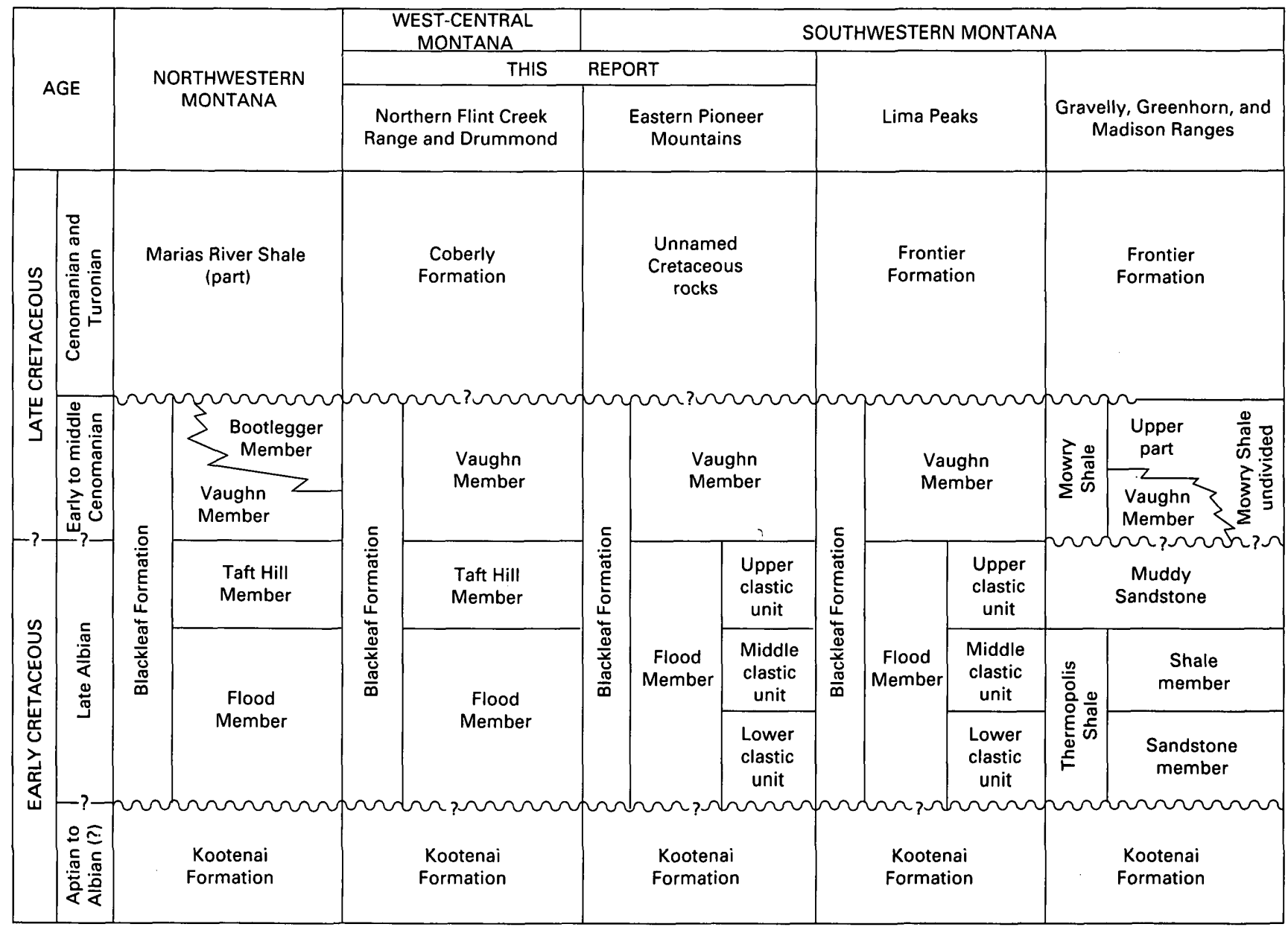

Figure 2. Simplified stratigraphic chart showing relationship between the Vaughn Member of the Blackleaf Formation and overlying and underlying strata in western Montana.

Mountains. The Vaughn Member contains abundant porcellanitic ${ }^{1}$ mudstone, siltstone, lithic-rich sandstone, and subordinate conglomerate and varies in thickness from 880 $\mathrm{ft}(268 \mathrm{~m})$ at the Lima Peaks section, to $1,950 \mathrm{ft}(594 \mathrm{~m})$ at the Rock Creek section, to $2,488 \mathrm{ft}(758 \mathrm{~m})$ at the Drummond section. Near Drummond, the Blackleaf Formation is subdivided into the Flood, Taft Hill, and Vaughn Members. The Taft Hill Member, composed of glauconitic- and lithic-rich sandstone, is not recognized in the eastern Pioneer Mountains (Cobban and others, 1976; Dyman and Tysdal, 1990) (fig. 2). Refer to Tysdal and others (1989a, b), Dyman and others (1989), Dyman and Tysdal (1990), and Dyman and others (in press) for detailed discussions and measured sections of the Blackleaf Formation in southwestern Montana.

\footnotetext{
${ }^{1}$ The term "porcellanite" is used here for siliceous tuffaceous rocks that have a dull luster and hardness similar to unglazed porcelain. Porcellanite is texturally different from unaltered volcanic tuff but has the same origin. In some cases, the porcellanitic texture may have developed from subsequent thermal metamorphism of the volcanogenic rocks.
}

The Vaughn-Frontier contact at Lima Peaks is disconformable and is marked by a sharp lithologic break. The overlying Frontier Formation contains quartz- and chert-rich sandstone, mudstone, shale, and conglomerate. Unfortunately, no usable radiometric ages were obtained from this locality, and no other complete Blackleaf section is present between Lima Peaks and Frying Pan Gulch because of post-Blackleaf erosion. In the eastern Pioneer Mountains, the undivided Upper Cretaceous strata above this contact consist of lithic-rich sandstone, brown to dark-gray siltstone and mudstone, and quartzite-clast and chert-clast conglomerate. The upper contact of the Vaughn in this area is at the top of a porcellanite bed that consistently and directly overlies the highest maroon mudstone-siltstone bed of the upper part of the Vaughn, which here is generally associated with nonmarine micritic limestone and dark-gray shale. Farther to the north, near Drummond, the Blackleaf-Coberly contact is easily recognizable; maroon mudstone and siltstone and interbedded porcellanite are overlain sharply by marine salt-and-pepper sandstone and limestone of the Coberly Formation. The four most reliable radiometric ages were 


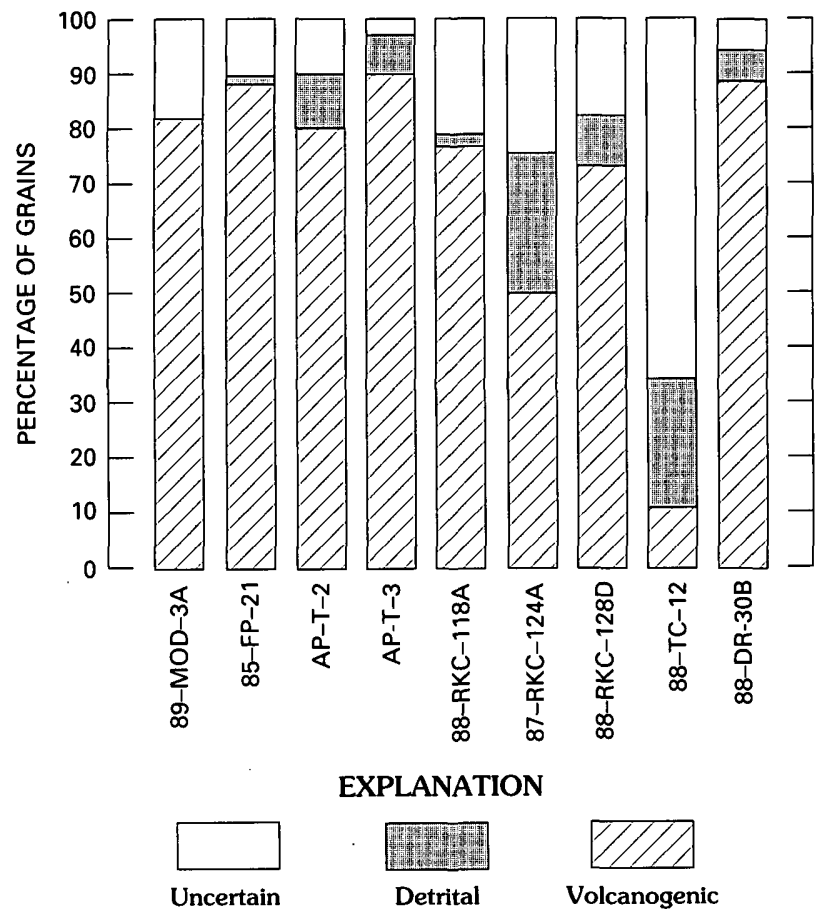

Figure 3. Relative abundances of morphological types of zircon. Volcanogenic zircon includes colorless to yellow, equant to moderately elongate, euhedral crystals, detrital zircon includes pink to red, rounded grains, and zircon described as uncertain includes various miscellaneous grains.

determined from the eastern Pioneer Mountains and at Drummond on porcellanites within the upper $837 \mathrm{ft}(255 \mathrm{~m})$ of the Vaughn.

Zircon of both volcanogenic and detrital origin is present in sparse amounts $(<1-50 \mathrm{ppm})$ in tuffaceous rocks of the Vaughn Member of the Blackleaf Formation. Preliminary attempts at dating the volcanogenic zircon, however, revealed that at least some grains have cores distinctly older than their overgrowth rims. After these initial measurements on 1-20-mg aliquots of zircon, a major effort was undertaken to refine the laboratory techniques for analyzing small amounts of young samples. By miniaturizing the bomb capsules and resin-exchange columns and decreasing the amounts of laboratory-introduced lead and uranium blanks, the amount of zircon required for analysis was reduced by an order of magnitude. In contrast to the preliminary work carried out on a milligram or more of the bulk samples, typically only $25-200$ grains $(0.1-0.8 \mathrm{mg})$ are needed for each determination.

Much of the subsequent effort concentrated on four samples that the earlier analyses had shown to contain the least proportion of inherited component. For these samples, individual grains were selected based on size, color, elongation, surface reflectance, and freedom from inclusions and cracks. Precise [and accurate] ${ }^{2}$ ages-ages having two standard deviation (95 percent confidence level) uncertainties of \pm 0.5 percent $[ \pm 1.2$ percent] or less-were obtained for three samples in which the complicating phenomena of inheritance and lead loss could be almost entirely avoided. Despite the use of similar selection techniques, the inherited component was enhanced rather than eliminated for the fourth sample, which was exhausted in the course of the study, and, consequently, the isotopic data result in a less precise interpreted age. Together, the four dated horizons establish an age interval of from $96.9 \pm 1.0 \mathrm{Ma}$ to $95-93 \mathrm{Ma}$ for the upper part of the Vaughn Member.

\section{ZIRCON MORPHOLOGY}

Between 5 and $500 \mathrm{mg}$ of zircon was recovered from approximately $10 \mathrm{~kg}$ of tuff for each of the nine samples investigated. Several different morphologies of zircon were recognized in the samples. These are tentatively classified as (1) colorless to yellow, equant to elongate, euhedral crystals of probable volcanic origin, (2) pink, rounded, detrital grains present in all samples, and (3) miscellaneous grains of uncertain origin, but which undoubtedly include broken and stained grains of the first two types. Modal abundances of the three morphological types for each sample are given in figure 3. All analyses were performed on the presumed volcanogenic zircon, and all other zircon grains were removed and excluded from further consideration.

Figures 4 and 5 are photomicrographs of representative volcanogenic zircon crystals from two of the dated samples (88-RKC-118A and 88-DR-30B) before additional evaluation and selection for analysis. Note the wide variations in crystal face development, inclusion abundances, crack abundances, and elongation displayed by crystals in each of these samples. Broken and highly cracked and included grains were eliminated prior to making the initial isotopic measurements on the 1-20-mg samples, but, otherwise, these early analyses are representative of the bulk size fractions into which the samples were screened. A more rigorous set of criteria was applied, however, to select the submilligram-size samples for the miniaturized chemical procedure. Generally, only the clearest, most inclusion- and crack-free, euhedral grains, representing 5-10 percent of the sample, were chosen for these later analyses. As will be discussed, elongation also became an important selection criteria for reducing the inherited component.

\section{ANALYSIS AND RESULTS}

The analytical procedure used prior to upgrading the laboratory is given in Zartman and others (1986). Results

\footnotetext{
${ }^{2}$ The distinction between precision and accuracy (the latter shown in brackets), as the terms are used in this paper, is discussed in the section on "Analysis and Results."
} 


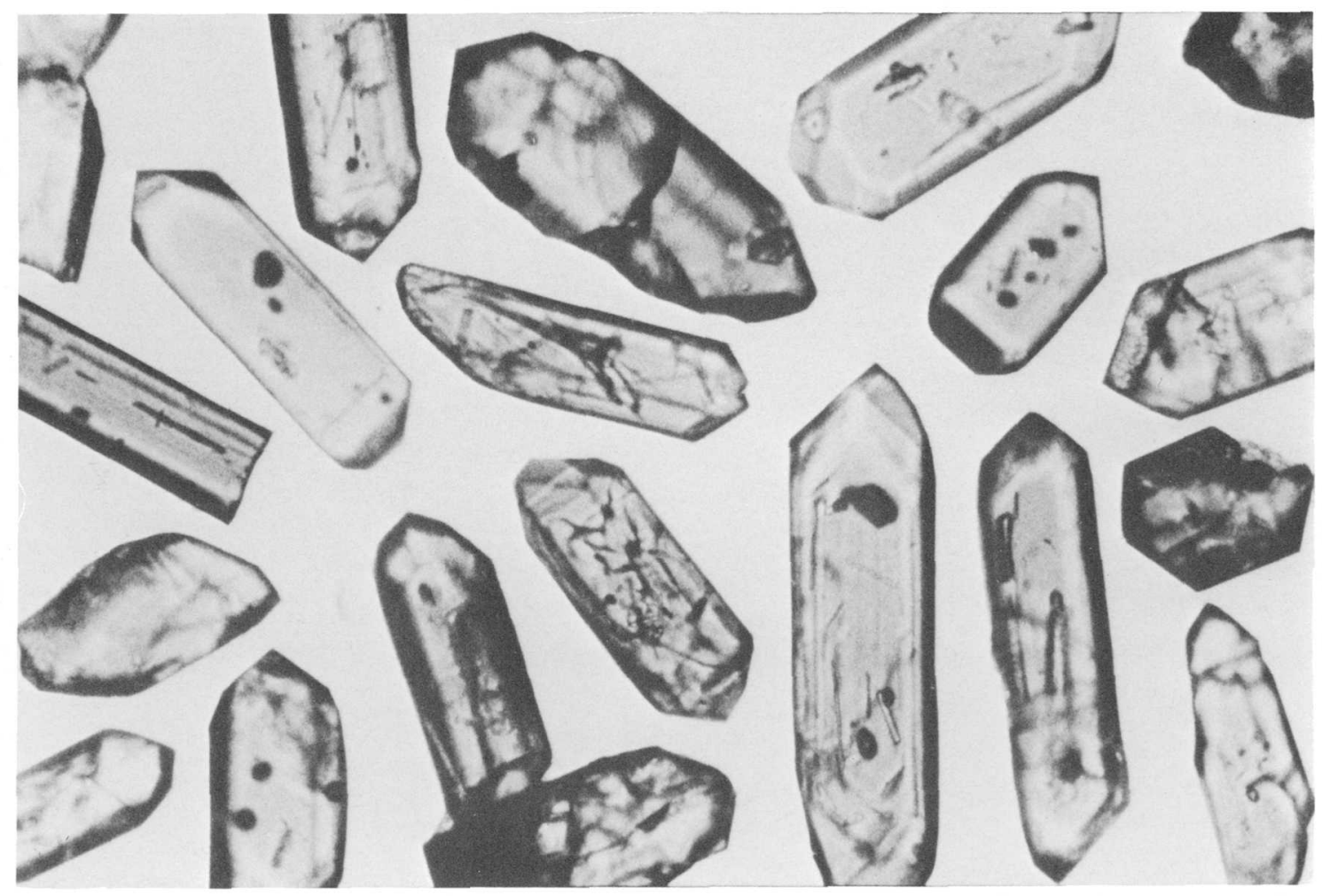

Figure 4. Photomicrograph of $-200+250$ mesh volcanogenic zircon from sample $88-$ RKC-118A showing euhedral morphology of most grains. Internally, the grains range from almost clear to highly fractured, turbid, and sometimes zoned. Some crystals have complexly developed terminations and uneven growth of equivalent pyramidal faces. $\times 250$, transmitted light.

obtained early in the study on samples weighing 1-20 mg are mainly of a reconnaissance nature and do not significantly affect the low errors assigned to those concordia-intercept ages, which are controlled by later, almost concordant analyses. Accordingly, we present only a brief description of those aspects of the revised procedure that made the greater precision and accuracy possible. The new, miniaturized analytical method is basically similar to that recently developed and employed by other laboratories (Parrish, 1987; Roddick and others, 1987), where it also has proven valuable for doing time-scale calibration with volcanogenic zircon (Samson and others, 1989; Roden and others, 1990; Tucker and others, 1990).

After selecting several dozen to several hundred zircon grains for each analysis, the grains are rinsed sequentially in hot $0.5 \mathrm{~N} \mathrm{HNO}_{3}$ and ultrapure $\mathrm{H}_{2} \mathrm{O}$ in a clean air environment. Following this treatment, any remaining grains with surface staining or adhering rock matrix or grains that broke during the cleaning process are removed. Next, aliquots of zircon weighing $0.15-0.72 \mathrm{mg}$ are loaded into $0.5-\mathrm{mL}$ capacity Teflon capsules together with $\mathrm{HNO}_{3}$ and a weighed amount of mixed ${ }^{205} \mathrm{~Pb}-{ }^{235} \mathrm{U}_{-}{ }^{230} \mathrm{Th}$ spike. The capsules are held in a puck above a reservoir of HF inside a hydrothermal bomb and heated to $215^{\circ} \mathrm{C}$ until the zircon is entirely digested, usually $5-10$ days. Chemical separation is carried out on $0.5-\mathrm{mL}$ resin-exchange columns, and the purified element is isotopically measured on an automated VG Isomass 54E single-collector mass spectrometer. Total chemistry blanks for $\mathrm{Pb}, \mathrm{U}$, and Th during the study were 10-25 (100) picograms (pg), 2 (10) pg, and 2 (10) pg, respectively (values in parentheses apply to >1-mg samples used before upgrading laboratory).

All but one of the almost concordant analyses crucial to the age determination have ${ }^{206} \mathrm{~Pb} /{ }^{204} \mathrm{~Pb}$ values greater than 1,000 ; thus, initial lead corrections were made by assuming model lead ratios at $95 \mathrm{Ma}$ (Stacey and Kramers, 1975) rather than by analyzing a coexisting phase from the porcellanite. Although in one case where ${ }^{206} \mathrm{~Pb} /{ }^{204} \mathrm{~Pb}=521$ this assumption could introduce an error of several million years in the ${ }^{207} \mathrm{~Pb} / 206 \mathrm{~Pb}$ age, it has virtually no effect on the more critical ${ }^{206} \mathrm{~Pb} / 238 \mathrm{U}$ age. The zircon U-Th- $\mathrm{Pb}$ isotopic data are presented in table 1 and are shown graphically in figures 7-11.

The effort to refine the stratigraphic assignment of the Vaughn Member requires that the geochronological data be evaluated in terms of both (1) intrinsic properties of the zircon, such as core-overgrowth relationships, metamictization, and initial lead content, and (2) analytical uncertainties inherent in the chemistry (weighing precision, blanks, and so forth) and mass spectrometry (beam intensity and stability, 


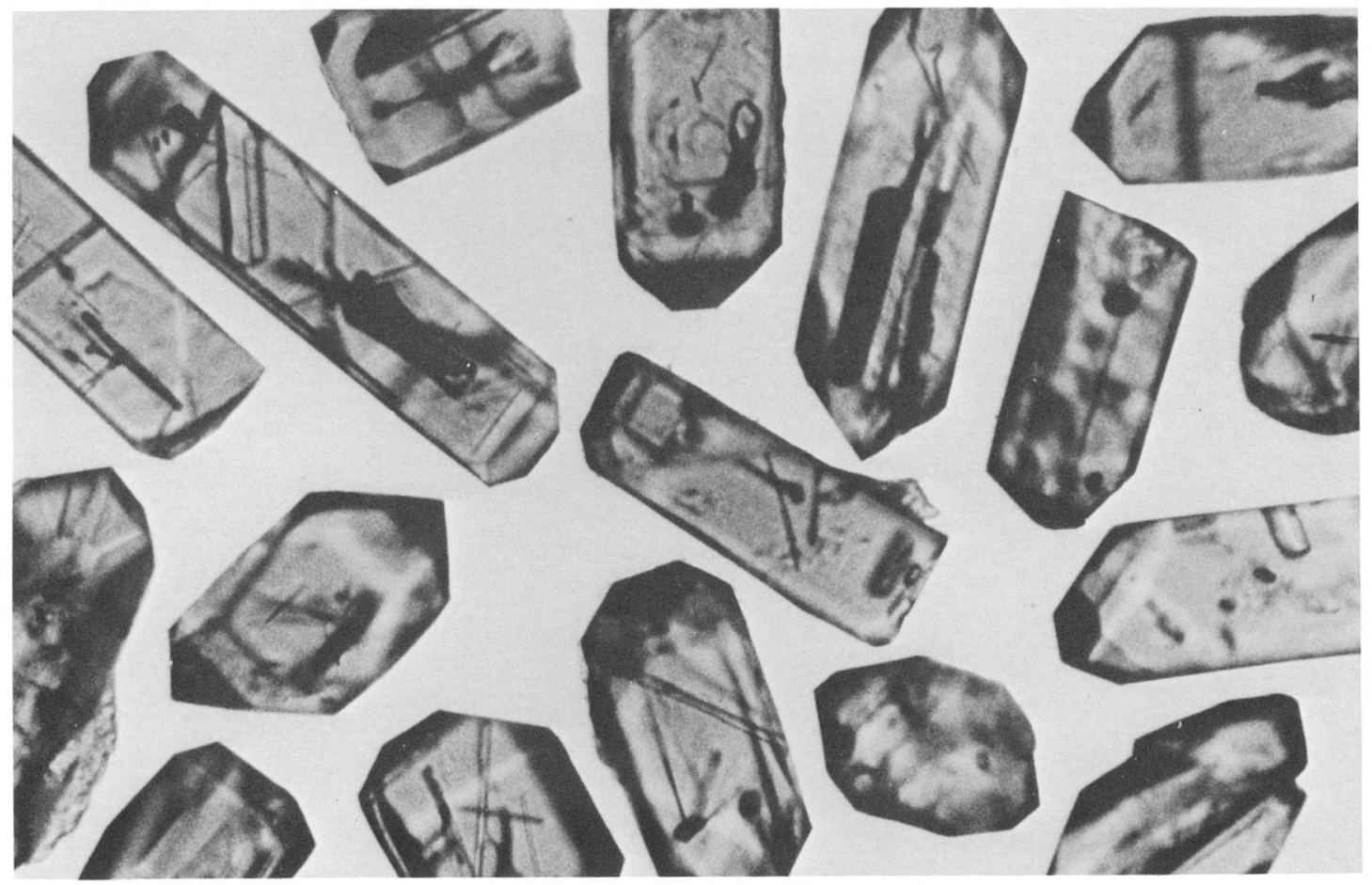

Figure 5. Photomicrograph of $-200+250$ mesh volcanogenic zircon from sample $88-D R-30 B$ showing euhedral morphology of most grains and, even more pronounced than in sample 88-RKC-118A, a markedly uneven development of pyramidal faces. Inclusions of apatite, opaque minerals, and mica are moderately abundant, and one hole is aligned perpendicular to the $c$-axis (upper right crystal). $\times 250$, transmitted light.

ion counting statistics, and so forth). Three computer programs were used to assign appropriate statistical parameters to mass spectrometric isotopic ratios (ANALYST; Ludwig, 1991a), calculated sample ages (PBDAT; Ludwig, 1991b), and concordia intercepts ages (ISOPLOT; Ludwig, 1991c). Variants of these programs have been used in our laboratory for several years, and the reader is referred to the referencing documents for a description of each program's function in the data reduction. Throughout the text, the convention is adopted of quoting all analytical errors at the two standard deviation $(2 \sigma)$ level.

A distinction is made between precision and accuracy of the calculated ages, arising from the independent calibration of the mixed ${ }^{205} \mathrm{~Pb}^{235} \mathrm{U}^{230} \mathrm{Th}$ spike. Age precision, a measurement of analytical reproducibility, is directly calculated from the error propagation equations of Ludwig (1991b) for a mixed spike of fixed concentration, whereas accuracy, a measurement of correctness, is calculated by including an additional factor for uncertainty in spike calibration. The distinction is important when the ages of different porcellanite beds are evaluated on the basis of their precision for relative stratigraphic order and when numerical age values are compared on the basis of their accuracy with other dating studies.
Essential to the accuracy of the U-Pb and Th- $\mathrm{Pb}$ ages is the ability to calibrate the mixed ${ }^{205} \mathrm{~Pb}^{235} \mathrm{U}^{230} \mathrm{Th}$ spike that was used during the latter stage of this work. Documentation for replicate spike calibrations bracketing these crucial analyses and for a zircon standard that was run concurrently is given in table 2 . From the $2 \sigma$ errors assigned to the ${ }^{205} \mathrm{~Pb}$, ${ }^{235} \mathrm{U}$, and ${ }^{230} \mathrm{Th}$ spike concentrations, $2 \sigma$ errors are derived for the ${ }^{205} \mathrm{~Pb} /{ }^{235} \mathrm{U}$ and ${ }^{205} \mathrm{~Pb} /{ }^{230} \mathrm{Th}$ in the spike of \pm 0.72 percent and \pm 0.94 percent, respectively. ( $2 \sigma$ errors of \pm 1.2 percent were used for these ratios in calculating the accuracy of ages determined with separate ${ }^{208} \mathrm{~Pb}$ and ${ }^{235} \mathrm{U}_{-}{ }^{230} \mathrm{Th}$ spikes during the early phase of the study.) These spike calibration errors are then combined with the age precision error of Ludwig (1991b, c) to derive the quoted accuracy of the U-Pb and $\mathrm{Th}-\mathrm{Pb}$ ages. A more sophisticated treatment of precision and accuracy, which takes into account error correlation and the nature of error distribution, may be possible if these factors can be analyzed but did not seem warranted by the present effort. Another consideration relevant to accuracy-uncertainties in the radioactive decay constants-is not considered here, and the values of Steiger and Jäger (1977) are adopted without critical review.

Four of nine samples provided isotopic ages of sufficiently high precision and accuracy to be useful for assigning meaningful chronostratigraphic dates. The most precise ages 

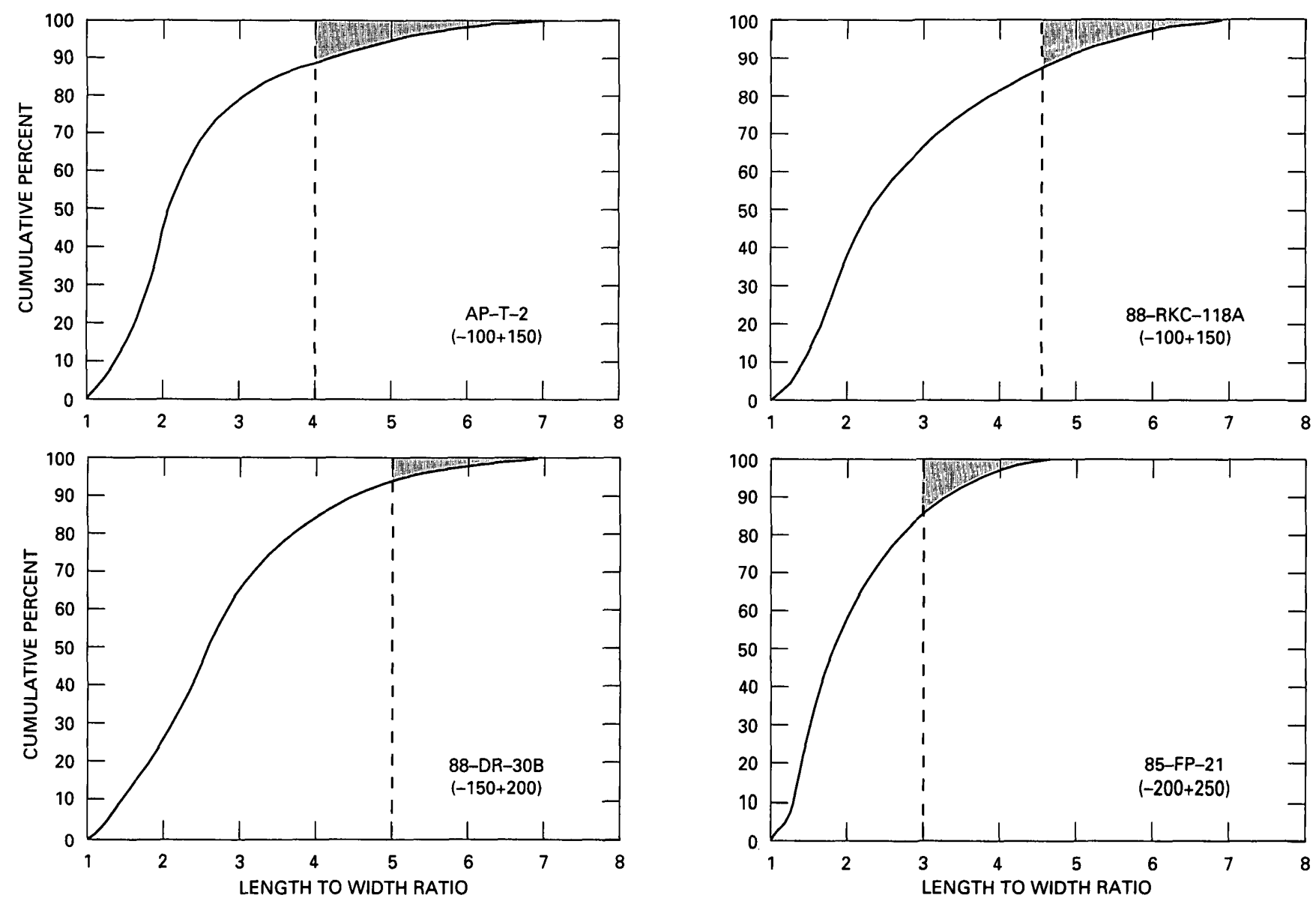

Figure 6. Cumulative plots of length to width ratio (elongation) of zircon from samples AP-T-2 (-100+150 mesh), 88-RKC-118A $(-100+150 \mathrm{mesh}), 88-\mathrm{DR}-30 \mathrm{~B}(-150+200 \mathrm{mesh})$, and $85-\mathrm{FP}-21(-200+250 \mathrm{mesh})$. These size fractions yielded the elongate crystals (shaded areas) and abraded crystal tips that resulted in analyses having a reduced inherited component.

were obtained on three samples (88-DR-30B, 88-RKC-118A, and AP-T-2) for which collinear arrays of five or more fractions were measured and one or two of the fractions are concordant within experimental uncertainty. Another array (sample 85-FP-21) gives an interpreted age range based on four size fractions but has no concordant fraction; in addition, an anomalous inherited component is present in one of the four fractions.

The exact location and distribution of the inherited component within the zircon populations is not well understood. Although only a weak correlation exists between the amount of inherited component and grain size within individual sample suites, the isotopic data can generally be interpreted in terms of core and overgrowth proportions. It is suspected, however, that a few of the grains identified as volcanogenic, especially in the earlier analyses, were instead xenocrystic, and their inclusion in the analyzed fractions greatly increased the amount of inherited component. For example, an analysis of only the clearest, least fractured, euhedral grains $(-100+150 \mathrm{CL}$ fraction) of sample 88-DR-30B reduced, but did not eliminate, the inheritance compared to a less critically selected fraction of the same mesh size.

Rare truncated zonal growth bands, fracture patterns, and contrasts in inclusion abundances outline core-overgrowth boundaries within single grains, but in most instances it is the isotopic data themselves that give evidence of an otherwise indiscernible inherited component. Where observable under the microscope, the core is usually equant to slightly elongate in outline, regardless of the shape of the overgrowth rim. This core-to-rim relationship is true even though some crystals have length to width ratios of $6: 1$ or greater. The most elongate grains within each sample can thus be expected to contain a high proportion of overgrowth component and, hence, to show diminished effects of inheritance.

For three samples (88-RKC-118A, AP-T-2, and 88-DR-30B) in which fractions consisting of the most elongate crystals (length to width ratio $\geq 4: 1$ ) were analyzed, simple calculations suggest that the longer crystals not only diminish the contribution of an inherited component in proportion to their core-to-rim volume ratio but also show a bias 


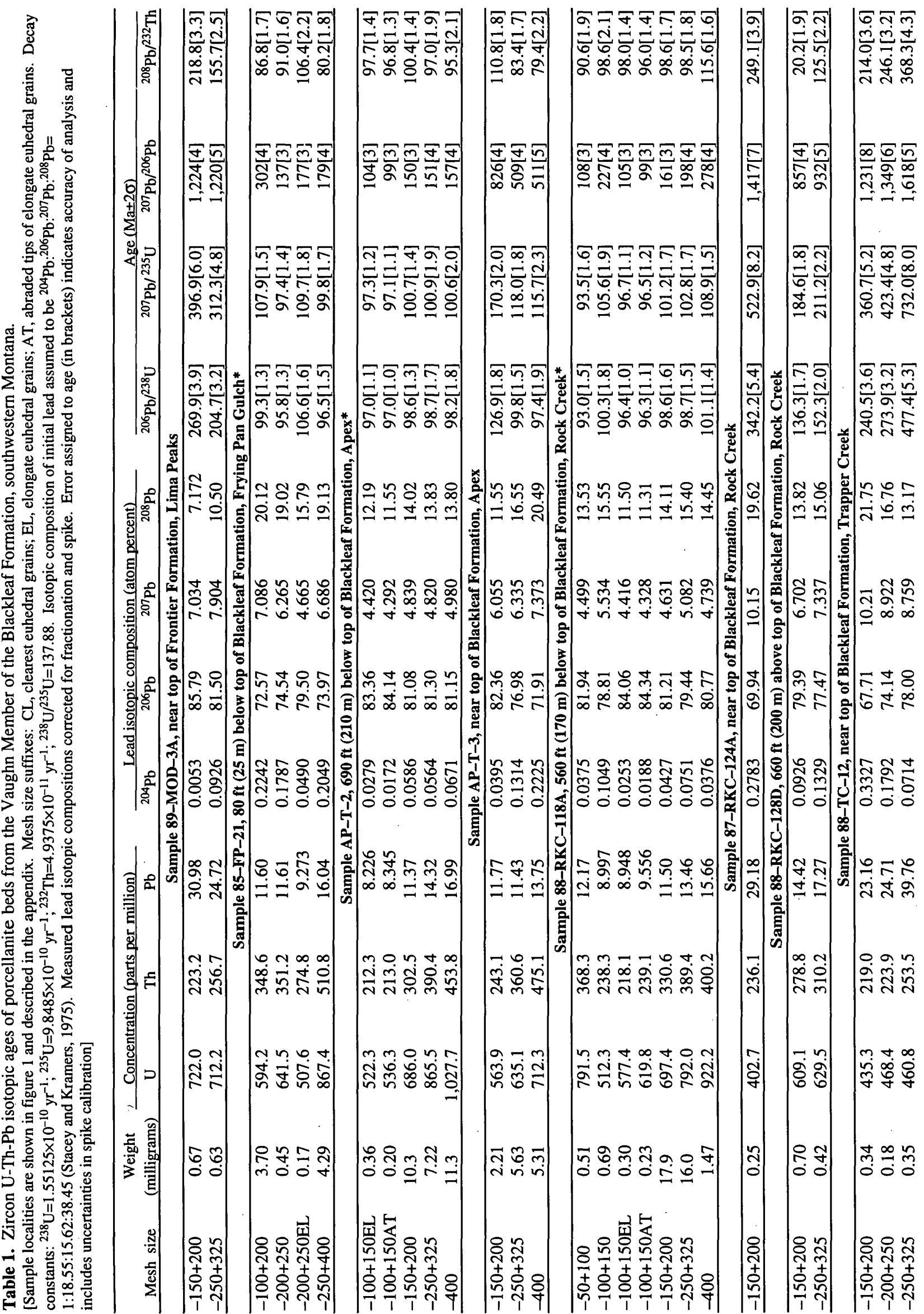


against nucleating cores. Quite possibly, the tendency to grow acicular zircon is a relatively late phenomenon in the evolution of a volcanic magma chamber, and, consequently, few nucleii survive to seed these latecomers. A fourth attempt (sample 85-FP-21) at analyzing an elongate fraction-albeit one having a lesser minimum length to width ratio of about 3:1—produced no similar improvement in reducing the inherited component, possibly due to the incorporation of an exotic grain into the analyzed material.

In a further effort to reduce the effects of inheritance, the elongate crystals from the three successful experiments described above were gently broken in a mortar. Fragments containing pyramidal terminations (hereafter called tips) were selected from the broken crystals and abraded briefly to remove surface contamination. Analyses of the tip fraction can be compared with those of the equivalent unbroken fractions (table 1); in every case, the abraded tips contained less ${ }^{204} \mathrm{~Pb}$ and yielded more nearly concordant ages. This virtual elimination of the inherited component permitted the determination of precise ages for three of the samples. Assigned uncertainties originate almost entirely from the analytical error of individual ${ }^{206} \mathrm{~Pb} /{ }^{238} \mathrm{U}$ age determinations rather than from the linear regression of a discordia line.

A comparison of $\mathrm{U}-\mathrm{Pb}$ and $\mathrm{Th}-\mathrm{Pb}$ ages (table 1 ) shows considerable discrepancies between these two dating methods. Although for those samples containing a large proportion of the inherited component, parent-daughter ages appreciably older than the stratigraphic age are recorded by both methods, many of the samples with minimal inheritance reveal a significant postcrystallization reduction of their $\mathrm{Th}-\mathrm{Pb}$ ages that is uncorrelated with their U-Pb ages. This decoupling of the decay schemes is frequently observed in igneous zircons and apparently implies that thorium and uranium are sited differently in the mineral, thereby allowing for selective loss of thorogenic lead. The possibility exists, however, that a small loss of uranogenic lead does accompany the loss of thorogenic lead. Of the four samples studied in detail, such an effect would be predicted to be greatest for samples 85-FP-21 and 88-DR-30B, for which the U-Pb and $\mathrm{Th}-\mathrm{Pb}$ age discrepancies are most pronounced. Fortunately, the disparity is not observed in the $-50+200 \mathrm{EL}$ and $-150+200 \mathrm{AT}$ fractions of sample $88-\mathrm{DR}-30 \mathrm{~B}$, which are concordant by all methods within experimental uncertainty and which mostly control the concordia lower intercept age. For these and other elongate and abraded tips of elongate zircon fractions, the good agreement of the $\mathrm{U}-\mathrm{Pb}$ and $\mathrm{Th}-\mathrm{Pb}$ ages is taken as an indication of the absence of an inherited component and of postcrystallization closed system behavior.

\section{SAMPLE AP-T-2}

The initial three analyzed size fractions of sample AP-T-2 contained, on the average, the least proportion of the inherited component of any sample in this study. 
Table 2. Calibration of mixed ${ }^{205} \mathrm{~Pb}-{ }^{235} \mathrm{U}-230 \mathrm{Th}$ spike and replicate analyses of standard zircon $\mathrm{S}-2-87$.

\begin{tabular}{|c|c|c|c|c|c|c|c|c|}
\hline \multicolumn{9}{|c|}{${ }^{205} \mathrm{~Pb}-{ }^{235} \mathrm{U}-{ }^{230} \mathrm{Th}$ spike calibration } \\
\hline & \multicolumn{2}{|c|}{$\begin{array}{c}{ }^{205} \mathrm{~Pb} \\
(\mu \text { moles/gram })\end{array}$} & & \multicolumn{2}{|c|}{$\begin{array}{c}{ }^{235} \mathrm{U} \\
(\mu \mathrm{moles} / \mathrm{gram})\end{array}$} & \multicolumn{3}{|c|}{$\begin{array}{c}{ }^{230} \mathrm{Th} \\
(\mu \mathrm{moles} / \mathrm{gram})\end{array}$} \\
\hline & \multicolumn{2}{|c|}{$\begin{array}{c}6.405 \pm 0.035 \times 10^{-5} \\
\pm 0.56 \text { percent } \\
10 \text { runs }\end{array}$} & & \multicolumn{2}{|c|}{$\begin{array}{c}5.753 \pm 0.025 \times 10^{-3} \\
\pm 0.45 \text { percent } \\
9 \text { runs } \\
\end{array}$} & \multicolumn{3}{|c|}{$\begin{array}{c}1.436 \pm 0.009 \times 10^{-3} \\
\pm 0.61 \text { percent } \\
11 \text { runs }\end{array}$} \\
\hline \multicolumn{9}{|c|}{ Standard zircon S-2-87 analyses } \\
\hline Weight & \multicolumn{2}{|c|}{$\begin{array}{c}\text { Concentration } \\
\text { (parts per million) }\end{array}$} & \multicolumn{3}{|c|}{ Lead isotopic composition } & \multicolumn{3}{|c|}{ Age $(\mathrm{Ma} \pm 2 \sigma)$} \\
\hline (milligrams) & $\mathrm{U}$ & $\mathrm{Pb}$ & ${ }^{206} \mathrm{~Pb} /{ }^{204} \mathrm{~Pb}$ & ${ }^{206} \mathrm{~Pb} /{ }^{207} \mathrm{~Pb}$ & ${ }^{206} \mathrm{~Pb} /{ }^{208} \mathrm{~Pb}$ & ${ }^{206} \mathrm{~Pb} /{ }^{238} \mathrm{U}$ & ${ }^{207} \mathrm{~Pb} /{ }^{235} \mathrm{U}$ & ${ }^{207} \mathrm{~Pb} /{ }^{206} \mathrm{~Pb}$ \\
\hline 2.62 & 201.5 & 13.45 & 1,625 & 15.81 & 4.391 & $372(2)$ & $373(2)$ & $381(1)$ \\
\hline 0.58 & 208.2 & 13.55 & 3,114 & 16.97 & 4.621 & 369 (1) & $371(1)$ & $381(2)$ \\
\hline 0.22 & 208.3 & 13.73 & 2,273 & 16.50 & 4.636 & $373(3)$ & 374 (2) & $379(4)$ \\
\hline 0.64 & 208.1 & 14.04 & 1,388 & 15.43 & 4.311 & $373(1)$ & $375(1)$ & $385(4)$ \\
\hline 0.28 & 211.3 & 13.71 & 6,917 & 7.74 & 4.764 & $372(2)$ & $373(2)$ & $382(1)$ \\
\hline 0.19 & 208.4 & 14.22 & 1,057 & 14.68 & 4.190 & $373(1)$ & $375(1)$ & $385(4)$ \\
\hline
\end{tabular}

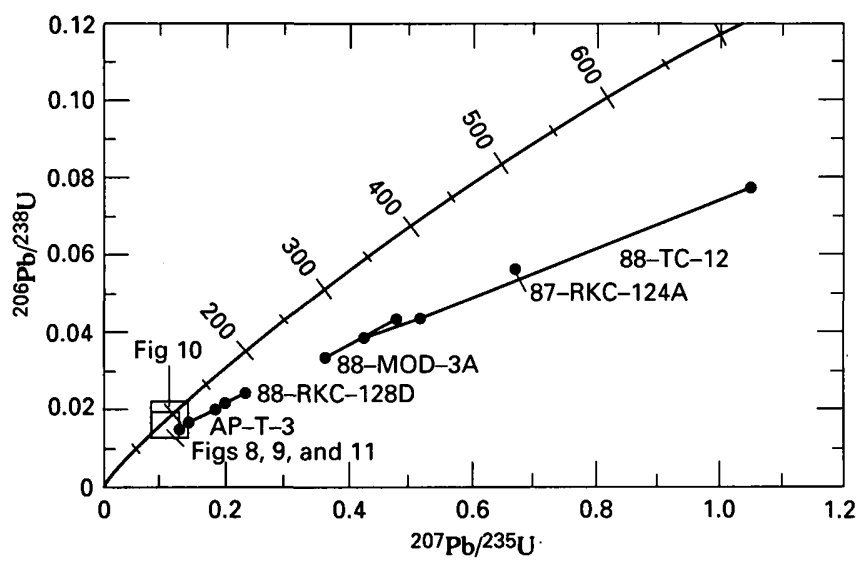

Figure 7. Concordia diagram showing ranges in isotopic composition for all samples. Individual data points for four samples, which contain a sufficiently low proportion of an old, inherited component to yield useful ages, plot within the boxes labeled as subsequent figures and are not plotted here.

Nevertheless, despite considerable variation in uranium content (686-1,028 ppm), all three fractions plot essentially coincidently on a concordia diagram (fig. 8), and, consequently, no discordia can be defined and a lower intercept age is only approximately definable if an age of 1.9-1.5 Ga based on the upper intercepts of other samples (see fig. 7 and following) is assumed for the inherited component.

When elongated, unbroken crystals from the $-100+150$ mesh fraction (length to width ratio $\geq 4: 1$, representing about 12 percent of the total zircon population in this mesh fraction) (fig. 6) were selected and analyzed, almost all of the inherited component was avoided. The abraded tips of these elongate crystals yielded a more nearly concordant result,

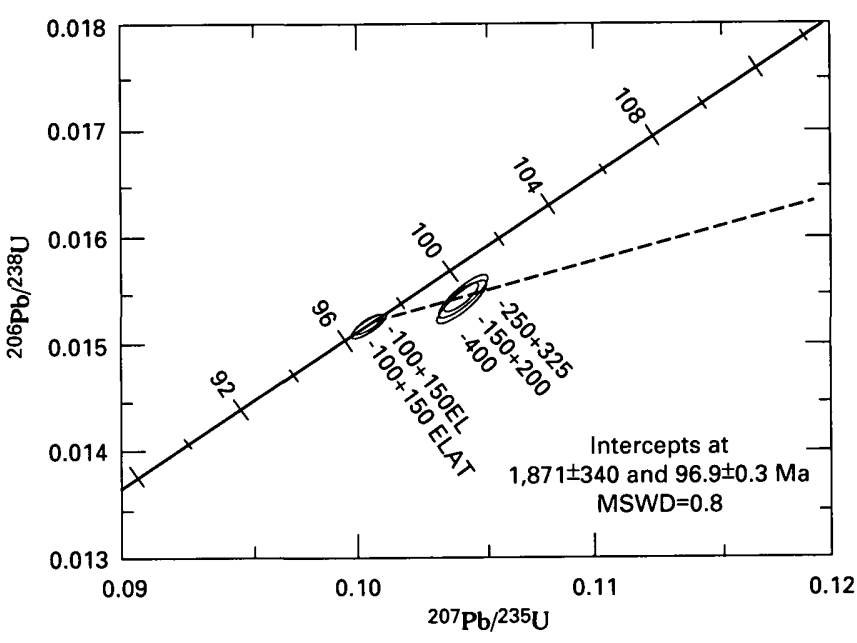

Figure 8. Concordia diagram for sample AP-T-2.

and, together, these two and the initial three analyses tightly constrain the concordia lower intercept to a model $1^{3}$ age of $96.9 \pm 0.3 \mathrm{Ma}$ (MSWD=0.8), the most precise of the study. An average age of the inherited component is less well defined by a long projection of the discordia to an upper intercept of 1,871 $\pm 340 \mathrm{Ma}$. Added support for the validity of the concordia lower intercept age is provided by the $\mathrm{Th}-\mathrm{Pb}$ ages of 95.0 and, especially, $96.8 \mathrm{Ma}$ for the $-100+150 \mathrm{EL}$ and $-100+150 \mathrm{AT}$ fractions, respectively.

\footnotetext{
${ }^{3}$ The linear regression fit to discordia is calculated using the ISOPLOT computer program of Ludwig (1991c). Models 1 (points weighted proportional to the inverse square of their assigned errors, after York, 1969) and $4 \mathrm{~L}$ (points weighted according to both assigned error and distance from lower concordia intercept) for calculating age and MSWD are especially relevant to this study.
} 


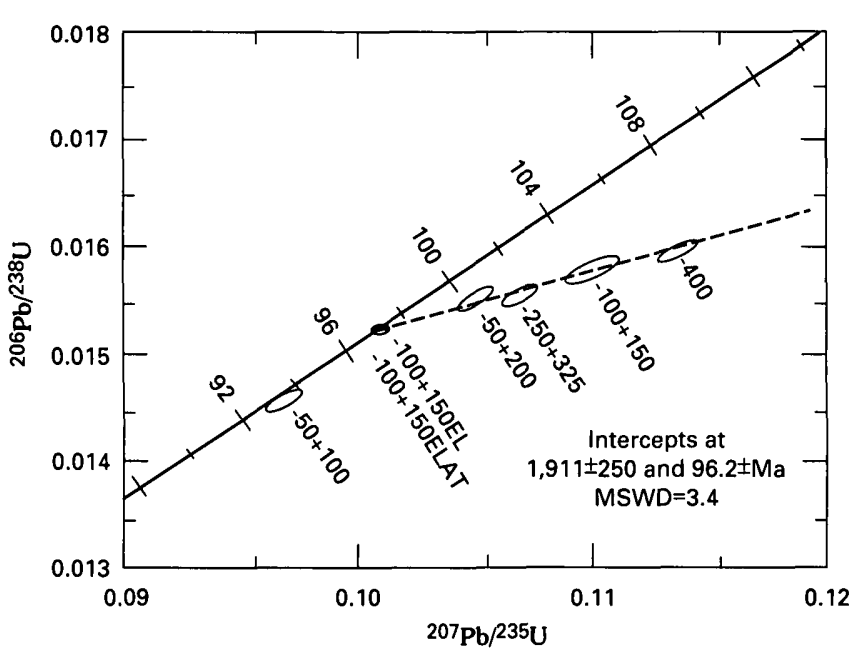

Figure 9. Concordia diagram for sample 88-RKC-118A.

\section{SAMPLE 88-RKC-118A}

Three initial and two subsequent analyses of sample 88-RKC-118A produced a somewhat linear array on a concordia diagram (fig. 9); however, the coarsest and seemingly most concordant $-50+100$ mesh fraction lies distinctly below the line defined by the other four fractions. Elongate, unbroken crystals were analyzed from the $-100+150$ mesh fraction (length to width ratio $\geq 4.5: 1$, representing about 12 percent of the total zircon population in this mesh fraction) (fig. 6), and, again, only a trace of the inherited component present in the unbiased $-100+150$ mesh fraction remained. Slightly more concordant but otherwise almost identical ages were also obtained from analyses of the abraded tips of these elongate crystals. With the exclusion of the $-50+100$ mesh fraction, a model 4L discordia was fit to the six other analytical points, yielding a lower intercept age of $96.2 \pm 0.4$ $\mathrm{Ma}$ (MSWD=3.4). An upper intercept age of $1,911 \pm 250 \mathrm{Ma}$ for the inherited component is essentially identical with the age for sample AP-T-2. Again, support for the concordia lower intercept age is provided by the $\mathrm{Th}-\mathrm{Pb}$ ages of 95.3 and 96.0 Ma for the $-100+150 \mathrm{EL}$ and $-100+150 \mathrm{AT}$ fractions, respectively.

It is uncertain why the $-50+100$ mesh fraction lies significantly below the discordia defined by the other fractions, but its position suggests postcrystallization lead loss from one or more degraded grains. This fraction contrasts with the trend of increasing uranium and thorium with decreasing grain size displayed by the other mesh sizes; thus, a particularly radioactive grain or contained inclusion might account for its lowered age. Interestingly, the $-50+100$ fraction also gives a $\mathrm{Th}-\mathrm{Pb}$ age that is younger than that for any other fraction of this sample, another suggestion of postcrystallization lead loss.

\section{SAMPLE 88-DR-30B}

All fractions of sample 88-DR-30B were analyzed after upgrading of the chemistry procedure. Four size fractions plot as an approximate linear array on a concordia diagram (fig. 10); the coarsest $(-100+150)$ and finest $(-400)$ fractions display the greatest proportion of the inherited component. A repeat analysis of the coarsest fraction, but comprising only the very clearest grains, showed a lower proportion of the inherited component than the first analysis. Once more, the method to virtually eliminate the inherited component is selection of elongate, unbroken crystals-in this case, from the $-150+200$ mesh fraction (length to width ratio $\geq 5: 1$, representing about 8 percent of the total zircon population in this mesh fraction) (fig. 6). Furthermore, the abraded tips of these elongate crystals yielded ages that are concordant within experimental uncertainty. Our estimated measurement uncertainty of \pm 0.1 percent in ${ }^{207} \mathrm{~Pb} /{ }^{206} \mathrm{~Pb}$ produces an error of $\pm 2.4 \mathrm{Ma}$ in the ${ }^{207} \mathrm{~Pb} /{ }^{206} \mathrm{~Pb}$ age. $\mathrm{A}$ discordia constructed from all seven analyses has a lower intersection with concordia that gives a model $4 \mathrm{~L}$ age of 95.4 $\pm 0.4 \mathrm{Ma}$ (MSWD=4.5). The age of the inherited component of $1,784 \pm 490 \mathrm{Ma}$, as defined by the upper concordia intercept, is slightly younger than, but statistically indistinguishable from, that of the prior two samples. Possibly a clue to the somewhat high MSWD for the discordia is the variable postcrystallization disturbance revealed by the $\mathrm{Th}-\mathrm{Pb}$ ages; if so, the convergence of the $\mathrm{Th}-\mathrm{Pb}$ ages to 97.0 and $96.7 \mathrm{Ma}$ for the $-150+200 \mathrm{EL}$ and $-150+200 \mathrm{AT}$ fractions, respectively-analytically indistinguishable from the concordia lower intercept age-suggests virtually no displacement of the lower discordia intercept.

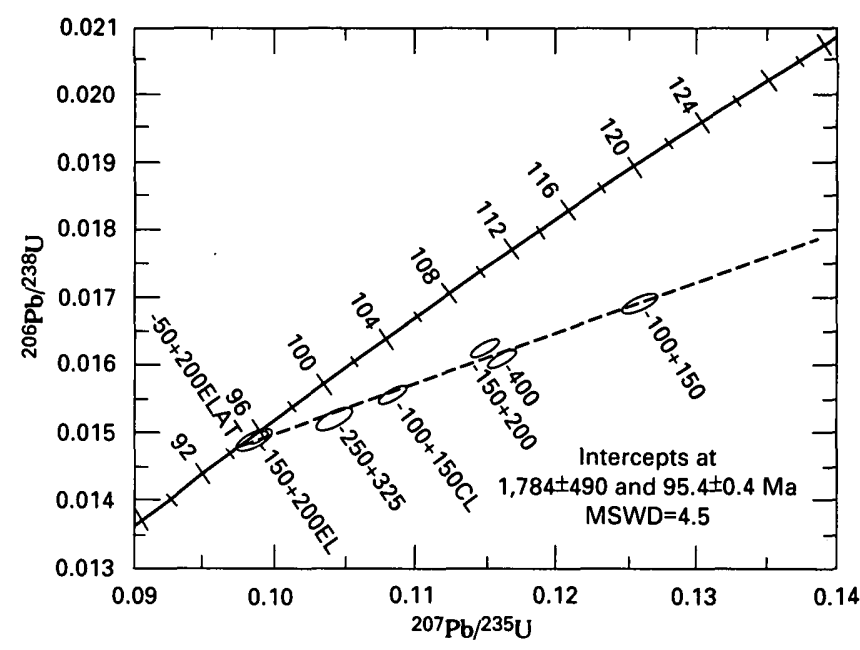

Figure 10. Concordia diagram for sample 88-DR-30B. 


\section{SAMPLE 85-FP-21}

Two initial and one subsequent size fractions of sample 85-FP-21 comprise a good linear array on a concordia diagram (fig. 11) that produces a model 1 intercept age of 94.8 $\pm 0.5 \mathrm{Ma}(\mathrm{MSWD}=0.6$ ). Unlike the three previous samples, which suggest a late Early Proterozoic (1,911-1,784 $\mathrm{Ma}$ ) age for the inherited component, this discordia projects to a significantly older upper intercept age of $2,280 \pm 170 \mathrm{Ma}$. This disparate upper intercept age, controlled mainly by the $-100+200$ mesh fraction, could indicate a different provenance for the magma giving rise to this tuff or, alternatively, postcrystallization disturbance of one or more of the analyzed fractions. Thus, although the scatter in this sample array as measured by the MSWD is low and can be accounted for entirely by analytical uncertainty, caution prevents placing much reliance on an age based on only three analyses.

The first three analyses depleted most of this sample, and only enough elongate crystals could be extracted from the $-200+250$ mesh fraction (length to width ratio $\geq 3: 1$, representing about 18 percent of the total zircon population in this mesh fraction) (fig. 6) to make one additional analysis. In this analysis the attempt to reduce the inherited component was unsuccessful, and, indeed, one or more grains of a distinctly different age component than observed previously probably were included. For example, when compared to the unbiased $-200+250$ mesh fraction, the anomalous position of the $-200+250 \mathrm{EL}$ fraction can readily be explained by the presence of a single $\sim 700$-Ma grain in the analyzed material. Because we were unable to repeat the analysis, no age of comparable precision to the prior three samples could be determined in this case. Assuming that neither of the two size fractions $(-200+250$ mesh and $-250+400$ mesh) plotting closest to concordia contains the anomalous inherited component nor has suffered postcrystallization radiogenic lead loss, an approximate age for sample 85-FP-21 may be calculated by subtracting a "normal" 1.8 - Ma inherited component from them. These calculated values, together with the model 1 age of 94.8 , produce a range of ages about $95 \mathrm{Ma}$ and $93 \mathrm{Ma}$. The $\mathrm{Th}-\mathrm{Pb}$ ages offer little additional insight except to question the assumption of no postcrystallization lead loss from the size fractions. Although inferior to the ages obtained for the other samples, a value of 95-93 Ma as the most likely age for this stratigraphically higher porcellanite bed is proposed.

\section{CONCLUSIONS}

This study demonstrates that, under optimum conditions, volcanogenic zircon, even that containing an older inherited component, is capable of yielding $\mathrm{U}-(\mathrm{Th})-\mathrm{Pb}$ isotopic ages that have a precision of \pm 1 percent $( \pm 1$ Ma for the mid-Cretaceous) or less. Paramount to the success of the

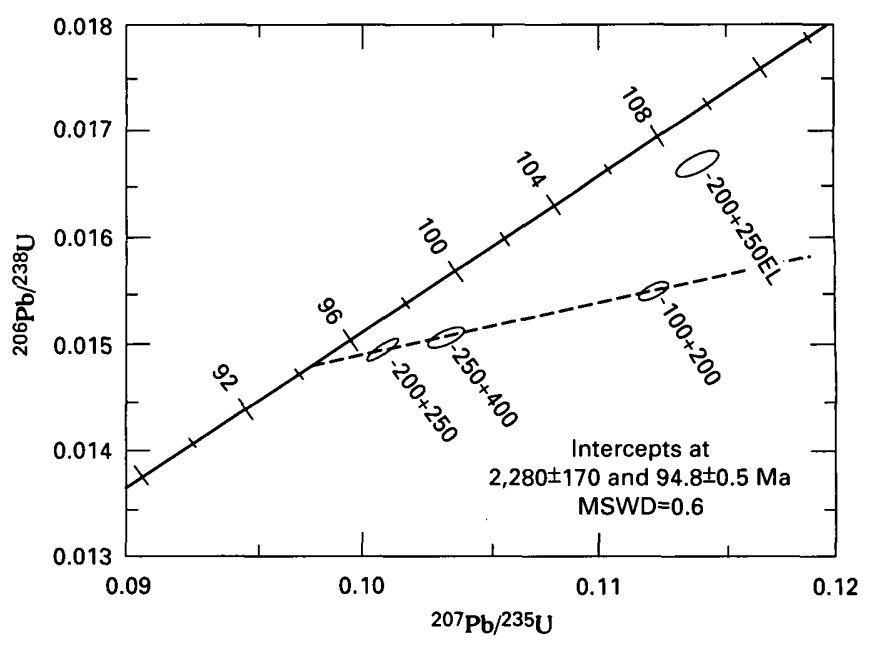

Figure 11. Concordia diagram for sample 85-FP-21.

present effort was the miniaturization of the analytical method, which made it possible to apply vigorous selection criteria in choosing the optimal grains, or parts of grains, for dating. Four ages were determined for the upper part of the Vaughn Member of the Blackleaf Formation in southwestern Montana (fig. 12). Two porcellanite beds approximately 690 $\mathrm{ft}(210 \mathrm{~m})$ and $560 \mathrm{ft}(170) \mathrm{m}$ below the top of the Vaughn in the eastern Pioneer Mountains (samples AP-T-2 and 88-RKC-118A, respectively) yielded precise [and accurate] ages of $96.9 \pm 0.3[ \pm 1.0] \mathrm{Ma}$ and $96.2 \pm 0.4[ \pm 1.1] \mathrm{Ma}$, respectively. Another bed $80 \mathrm{ft}(25 \mathrm{~m})$ below the top of the Vaughn in the eastern Pioneer Mountains (sample 85-FP-21) was less precisely dated at 95-93 Ma.

A porcellanite bed $840 \mathrm{ft}(255 \mathrm{~m})$ below the top of the Vaughn near Drummond about $80 \mathrm{mi}(130 \mathrm{~km})$ north of the Pioneer Mountains yielded an age of $95.4 \pm 0.4[ \pm 1.1] \mathrm{Ma}$ (sample 88-DR-30B). Although this sample is at a greater depth below the top of the Vaughn than those farther to the south, its age is slightly but resolvably younger than those of samples AP-T-2 and 88-RKC-118A. Compare, in particular, the ages and their precision of samples 88-DR-30B and AP-T -2 , which are $840 \mathrm{ft}(255 \mathrm{~m})$ and $690 \mathrm{ft}(210 \mathrm{~m})$ below the top of the Vaughn, respectively. One possible explanation of this apparent contradiction is that the Vaughn Member is considerably thicker at Drummond than in the Pioneer Mountains; considerable thickness variations laterally over several tens of miles are to be expected for a sequence of nonmarine strata. Because the porcellanite beds cannot be field correlated between localities, it is possible that the bed at Drummond, although stratigraphically deeper, is the younger unit. On the other hand, the possibility of minor radiogenic lead loss or other disturbance of the isotopic system-having the effect of translating the discordia arrays and slightly changing the concordia intercepts-cannot be entirely discounted. With these limited data it is perhaps unwise to assign more than a pooled age of 97-95 Ma (or 93 Ma) to the dated interval. 


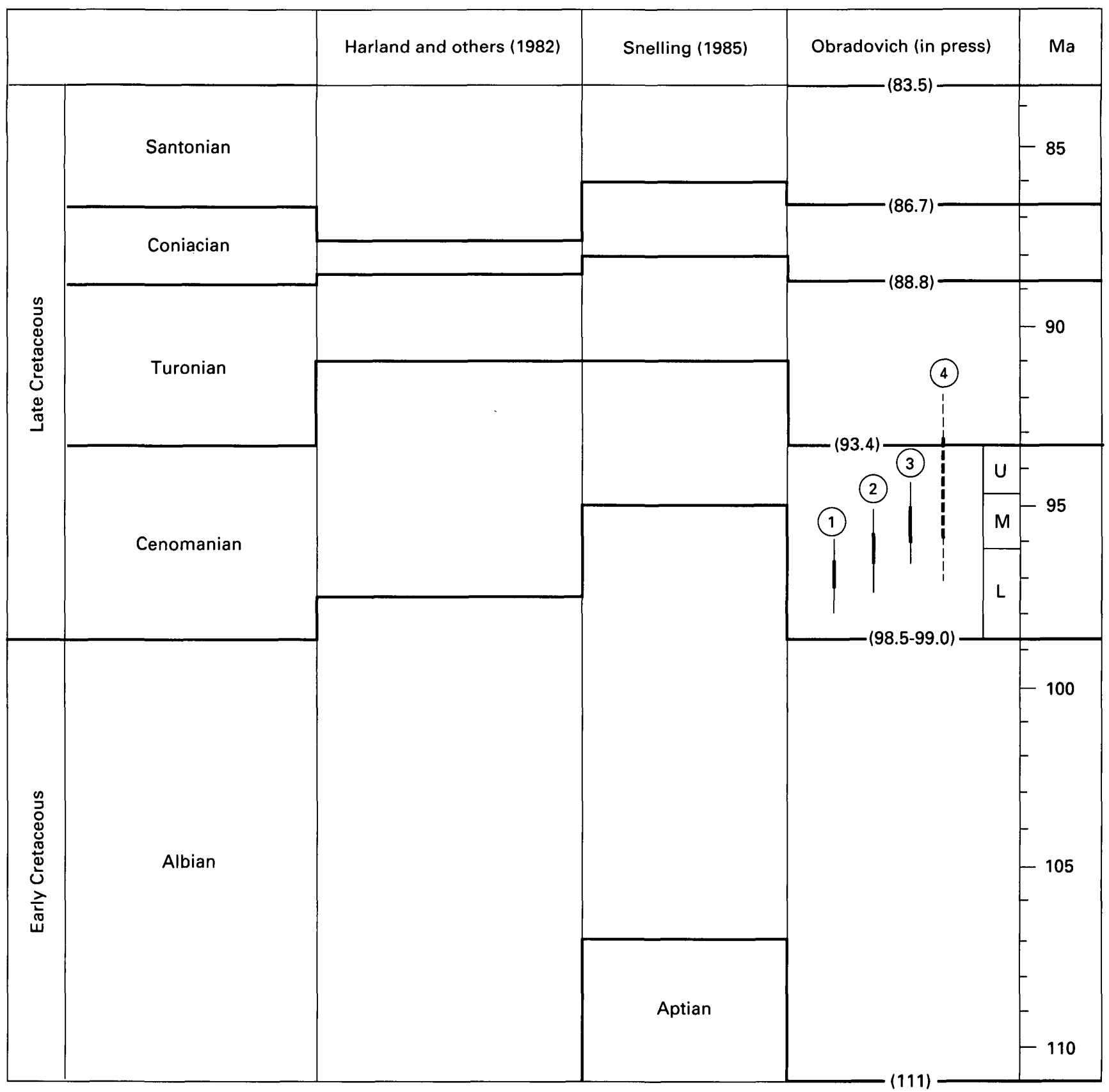

Figure 12. Chart showing geologic time scales of Harland and others (1982), Snelling (1985) and Obradovich (1993), presented for purpose of comparison. All age assignments in this paper are based on the Cretaceous time scale of Obradovich (1993), which specifically relates to the biostratigraphy of the Western Interior of the United States and contains considerable new radiometric data. Samples: 1, AP-T-2; 2, 88-RKC-118A; 3, 88-DR-30B; 4, 85-FP-21. Heavy and light bar ranges designate precision and accuracy, respectively; line for sample $85-\mathrm{FP}-21$ is dashed where age is interpretive (see text).

Thus, the upper part of the nonmarine Vaughn Member in southwestern Montana is established as early to middle Cenomanian based on the three best radiometric age determinations. The age agrees closely with that determined for the Vaughn Member of the Mowry Shale in the Madison Range, about $75 \mathrm{mi}(120 \mathrm{~km})$ east of the Pioneer Mountains, the nearest area where the Vaughn has been dated biostratigraphically. In the Madison Range, the marine Muddy
Sandstone lies directly beneath the Vaughn and regionally contains a late Albian species of ammonite (Tysdal and others, 1989b); marine strata of the Mowry lithostratigraphically correlative to the Vaughn yielded marine and nonmarine palynomorphs of early Cenomanian age. The palynomorphs previously were assigned to the late Albian (Tysdal and others, 1989a, b) but now are assigned to the early Cenomanian because of the revised biostratigraphic 
zonation of the Albian-Cenomanian boundary by Cobban and Kennedy (1989) (D.J. Nichols, oral commun., 1992). Recently, Obradovich (1993) determined an ${ }^{40} \mathrm{Ar}-{ }^{39} \mathrm{Ar}$ age on sanidine from the top of the Mowry Shale (Clay Spur Bentonite) at $97.2 \pm 0.7 \mathrm{Ma}$, an age in close agreement with the upper limit of our 97-95-Ma pooled age range

An additional contribution of this work is its use for identifying and locating the volcanic terrane that gave rise to the dated porcellanite beds. The early to middle Cenomanian age of volcanism and the presence of an Early Proterozoic (2,280-1,784 Ma) inherited component in the dated zircon provide two important clues about the anticipated geology of the terrane. That is, the terrane should show evidence (1) for contemporaneous volcanism and (or) plutonism and (2) for basement rock of appropriate age. Indeed, to the west the igneous and metamorphic rocks of the Idaho batholith contain both Proterozoic gneiss and Cretaceous and Tertiary plutonic rocks (Bickford and others, 1981; Fleck and Criss, 1985). In a recent U-Pb zircon geochronology study on the Bitterroot lobe of the Idaho batholith (Toth and Stacey, 1992), a biotite tonalite sample yielded a crystallization age of $94 \pm 1.4 \mathrm{Ma}$ and a minor component of old inherited zircon. Other Cretaceous and Tertiary monzogranites and granodiorites also revealed the inherited component, which projected on concordia diagrams to upper intercept ages of 1,810-1,620 Ma. Until more comparisons can be made, however, confirmation of the exact location of the volcanoes that produced the ashes contained in the Vaughn Member must await additional investigation. Nonetheless, it is an intriguing likelihood that morphologic, geochemical, and isotopic traits of the volcanogenic zircon have an important role to play in relating ashes to their volcanic terrane and, thus, in aiding reconstruction of regional paleogeography.

Acknowledgments. -We thank several of our colleagues who encouraged us to pursue the U-Pb dating of zircon in volcanic rocks as a method of obtaining precise stratigraphic ages. John Obradovich and William Cobban discussed their K-Ar dating and paleontologic work, respectively, on Aptian through Santonian rocks of western North America, which must be reckoned with our results in any consistent time scale. Kenneth Ludwig offered helpful suggestions about the use of his computer programs in the reduction of our data and, particularly, in the treatment of analytical errors. Special recognition is given to Loretta Kwak for performing the state-of-the-art chemistry and mass spectrometry that made this study possible. James Paces, a postdoctorate fellow in the laboratory at the time the analyses were made, also deserves our gratitude for his assistance in establishing the miniaturized chemistry procedure and in calibrating the mixed ${ }^{205} \mathrm{~Pb}-{ }^{235} \mathrm{U}_{-} 230 \mathrm{Th}$ spike.

\section{REFERENCES CITED}

Bickford, M.E., Chase, R.B., Nelson, B.K., Shuster, R.D., and Arruda, E.C., 1981, U-Pb studies of zircon cores and overgrowths, and monazite-Implications for age and petrogenesis of the northeastern Idaho batholith: Journal of Geology, v. 89, p. 433-457.

Cobban, W.A., 1991, Occurrence and significance of the Middle Turonian (Upper Cretaceous) belemnite Actinocamax in central western Montana, in Contributions to Late Cretaceous stratigraphy and paleontology, western Montana: U.S. Geological Survey Bulletin 1962, p. C23-26.

Cobban, W.A., Erdmann, C.E., Lemke, R.W., and Maughan, E.K., 1976, Type sections and stratigraphy of the members of the Blackleaf and Marias River Formations (Cretaceous) of the Sweetgrass arch, Montana: U.S. Geological Survey Professional Paper 974, 66 p.

Cobban, W.A., and Kennedy, W.Q., 1989, The ammonite Metengonoceras Hyatt, 1903, from the Mowry Shale (Cretaceous) of Montana and Wyoming: U.S. Geological Survey Bulletin 1787-L, 23 p.

Dyman, T.S., Haley, C.J., and Perry, W.J., Jr., 1991, Revision of Frontier Formation-Beaverhead Group contact, Lima Peaks area, southwestern Montana and southeastern Idaho: U.S. Geological Survey Bulletin 1962, 8 p.

Dyman, T.S., and Nichols, D.J., 1988, Stratigraphy of mid-Cretaceous Blackleaf and lower part of the Frontier Formations in parts of Beaverhead and Madison Counties, Montana: U.S. Geological Survey Bulletin 1773, 31 p.

Dyman, T.S., Perry, W.J., Jr, Nichols, D.J., Davis, L.E., and Haley, J.C., 1989, Stratigraphy, petrology, and provenance of the Cenomanian to Turonian Frontier Formation near Lima, southwest Montana, in French, D.E., and Grabb, R.F., eds., Geologic resources of Montana: Montana Geological Society Field Conference, 1989, Guidebook, p. 103-114.

Dyman, T.S., and Tysdal, R.G., 1990, Correlation chart of Lower and Upper Cretaceous Blackleaf Formation, Lima Peaks area to eastern Pioneer Mountains, southwestern Montana: U.S. Geological Survey Miscellaneous Field Studies Map MF-2119.

Dyman, T.S., Tysdal, R.G., Wallace, C.A., and Lewis, S.E., in press, Correlation chart of Lower and Upper Cretaceous Blackleaf Formation, eastern Pioneer Mountains, southwestern Montana, to Drummond, central-western Montana: U.S. Geological Survey Miscellaneous Investigations Map I-2478.

Fleck, R.J., and Criss, R.E., 1985, Geochronometry of two-mica granitic rocks of the Idaho batholith: Geological Society of America Abstracts with Programs, v. 17, p. 218.

Gwinn, V.E., 1965, Cretaceous rocks of the Clark Fork Valley, central-western Montana: Billings Geological Society Annual Field Conference, 16th, Guidebook, p. 34-37.

Harland, W,B., Cox, A.V., Llewellyn, P.G., Pickton, C.A.G., Smith, A.G., and Walters, R.W., 1982, A geologic time scale: Cambridge, Cambridge University Press, $131 \mathrm{p}$. 
Ludwig, K.R., 1991a, User's guide to ANALYST, a computer program for control of an Isomass 54E thermal-ionization, single-collector mass-spectrometer (rev.): U.S. Geological Survey Open-File Report 85-142, 97 p.

-1991b, PBDAT, a computer program for processing $\mathrm{Pb}-\mathrm{U}-\mathrm{Th}$ isotopic data (rev.): U.S. Geological Survey Open-File Report 88-542, 34 p.

-1991c, ISOPLOT_A plotting and regression program for radiogenic-isotope data: U.S. Geological Survey Open-File Report 91-445, 41 p.

Obradovich, J.D., 1993, A Cretaceous timescale, in Caldwell, W.G.E., and Kauffman, E., eds., Evolution of the Western Interior basin: Geological Association of Canada Special Publication 39, p. 379-396.

Parrish, R.R., 1987, An improved microcapsule for zircon dissolution in U-Pb geochronology: Chemical Geology (Isotope Geoscience Section), v. 66, p. 99-102.

Roddick, J.C., Loveridge, W.D., and Parrish, R.R., 1987, Precise $\mathrm{U} / \mathrm{Pb}$ dating of zircon at the sub-nanogram $\mathrm{Pb}$ level: Chemical Geology (Isotope Geoscience Section), v. 66, p. 111-121.

Roden, M.K., Parrish, R.R., and Miller, D.S., 1990, The absolute age of the Eifelian Tioga ash bed, Pennsylvania: Journal of Geology, v. 98, p. 282-285.

Samson, S.D., Patchett, P.J., Roddick, J.C., and Parrish, R.R., 1989, Origin and tectonic setting of Ordovician bentonites in North America-Isotopic and age constraints: Geological Society of America Bulletin, v. 101, p. 1175-1181.

Snelling, N.J., 1985, An interim time-scale, in Snelling, N.J., ed., The chronology of the geological record: Geological Society of London Memoir 10, p. 261-265.

Stacey, J.S., and Kramers, J.D., 1975, Approximation of terrestrial lead isotope evolution by a two-stage model: Earth and Planetary Science Letters, v. 26, p. 207-221.

Steiger, R.H., and Jäger, E., 1977, Convention on the use of decay constants in geo- and cosmochronology: Earth and Planetary Science Letters, v. 36, p. 359-362.

Toth, M.I., and Stacey, J.S., 1992, Constraints on the formation of the Bitterroot Lobe of the Idaho batholith, Idaho and Montana, from $\mathrm{U}-\mathrm{Pb}$ zircon geochronology and feldspar $\mathrm{Pb}$ isotopic data: U.S. Geological Survey Bulletin 2008, 14 p.

Tucker, R.D., Krogh, T.E., Ross, R.J., Jr., and Williams, S.H., 1990, Time-scale calibration by high-precision $\mathrm{U}-\mathrm{Pb}$ zircon dating of interstratified volcanic ashes in the Ordovician and Lower Silurian stratotypes of Britian: Earth and Planetary Science Letters, v. 100, p. 51-58.

Tysdal, R.G., Dyman, T.S., and Nichols, D.J., 1989a, Correlation chart of Lower Cretaceous rocks, Madison Range to Lima Peaks area, southwestern Montana: U.S. Geoogical Survey Miscellaneous Field Studies Map MF-2067.

1989b, Lower Cretaceous bentonitic strata in southwestern Montana assigned to Vaughn Member of Mowry Shale (east) and Blackleaf Formation (west): The Mountain Geologist, v. 26, p. 53-61.

Tysdal, R.G., Dyman, T.S., Nichols, D.J., and Cobban, W.A., 1990, Correlation chart of Frontier Formation from Greenhorn Range, southwestern Montana, to Mount Everts in Yellowstone National Park, Wyoming: U.S. Geological Survey Miscellaneous Field Studies Map MF-2116, 16 p.

Wallace, C.A., Lidke, D.J., and Schmidt, R.G., 1990, Faults of the central part of the Lewis and Clark line and fragmentation of the Late Cretaceous foreland basin in west-central Montana: Geological Society of America Bulletin, v. 102, p. 1021-1037.

Wallace, C.A., Schmidt, R.G., Lidke, D.J., Waters, M.R., Elliot, J.E., French, A., Whipple, J.W., Zarske, S.E., Blaskowski, M.J., Yeoman, R.A., O'Neill, J.M., Lopez, D.A., Robinson, G.D., and Klepper, M.R., 1986, Preliminary map of the Butte $1^{\circ} \times 2^{\circ}$ quadrangle, western Montana: U.S. Geological Survey Open-File Report 86-292.

York, D., 1969, Least-squares fitting of a straight line with correlated errors: Earth and Planetary Science Letters, v. 5, p. 320-324.

Zartman, R.E., Kwak, L.M., and Christian, R.P., 1986, U-Pb systematics of a mixed zircon population-The granite at Yale Farm, Berkshire Massif, Connecticut, in Peterman, Z.E., and Schnabel, D.C., eds., Shorter contributions to isotope research: U.S. Geological Survey Bulletin 1622, p. 81-98. 


\section{APPENDIX-DETAILS OF SAMPLE LOCALITIES}

[Sample localities are shown in figure 1]

89-MOD-3A.-Modoc Creek measured section of Dyman and others (1991). SE $1 / 4$ sec. 33, T. 14 N., R. 35 E., Paul Reservoir 7.5-minute quadrangle, Beaverhead County, Montana. Uppermost porcellanite of Frontier Formation 80 $\mathrm{ft}(25 \mathrm{~m})$ below base of Beaverhead Group.

85-FP-21.-Frying Pan Gulch measured section of Dyman and Tysdal (1990). Sec. 30, T. 6 S., R. 9 W., Bond 7.5-minute quadrangle, Beaverhead County, Montana. Uppermost part of Vaughn Member of Blackleaf Formation $80 \mathrm{ft}(25 \mathrm{~m})$ below top of unit.

$A P-T-2 .-A p e x$ measured section of Dyman and Tysdal (1990). S 1/2 sec. 6 and SE $1 / 4$ sec. 7, T. 5 S., R. 8 W., Twin Adams Mountain 7.5-minute quadrangle, Beaverhead County, Montana. Upper part of Vaughn Member of Blackleaf Formation $690 \mathrm{ft}(210 \mathrm{~m})$ below top of unit.

AP-T-3.-Same location as AP-T-2. Uppermost porcellanite, which defines top of Vaughn Member of Blackleaf Formation.

88-RKC-118A.-Rock Creek measured section of Dyman and Tysdal (1990). Secs. 26, 27, and 28, T. 3 S., R. 10 W., Vipont Park 7.5-minute quadrangle, Beaverhead
County, Montana. Upper part of Vaughn Member of Blackleaf Formation $560 \mathrm{ft}(170 \mathrm{~m})$ below top of unit.

88-RKC-124A.-Same location as 88-RKC-118A. Uppermost porcellanite unit of Vaughn Member of Blackleaf Formation.

$88-R K C-128 D$. - Same location as $88-\mathrm{RKC}-118 \mathrm{~A}$. $660 \mathrm{ft}(200 \mathrm{~m})$ above top of Vaughn Member of Blackleaf Formation.

88-TC-12.-Trapper Creek measured section of Dyman and Tysdal (1990). S $1 / 2$ secs. 23 and 24, T. 2 S., R. 10 W., Vipont Park 7.5-minute quadrangle, Beaverhead County, Montana. Uppermost exposed porcellanite of Vaughn Member of Blackleaf Formation (actual contact covered).

88-DR-31B.-Drummond measured section (Tysdal and Dyman, unpub. data, measured in 1989-1990). Center of sec. 32 , T. 11 N., R. 12 W., southeastward to NE1/4 sec. 5 and $\mathrm{S} 1 / 2$ sec. 4 , T. 10 N., R. 12 W., Limestone Ridge 7.5-minute quadrangle, Granite County, Montana. Upper part of Vaughn Member of Blackleaf Formation $840 \mathrm{ft}(255$ m) from top of unit. 


\section{Occurrences of the Free-Swimming Upper Cretaceous}

Crinoids Uintacrinus and Marsupites in the Western Interior of the United States

By William A. Cobban

SHORTER CONTRIBUTIONS TO THE STRATIGRAPHY AND GEOCHRONOLOGY OF UPPER CRETACEOUS ROCKS IN THE WESTERN INTERIOR OF THE UNITED STATES

U.S. GEOLOGICAL SURVEY BULLETIN 2113-C

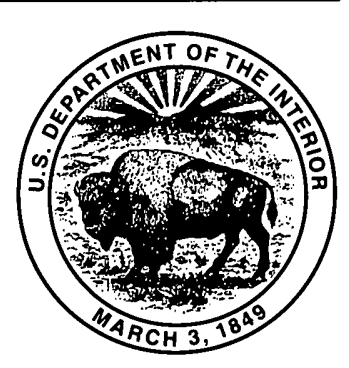

UNITED STATES GOVERNMENT PRINTING OFFICE, WASHINGTON : 1995 


\section{CONTENTS}

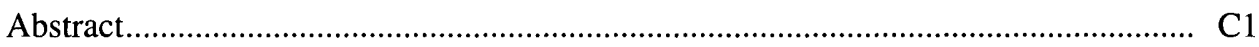

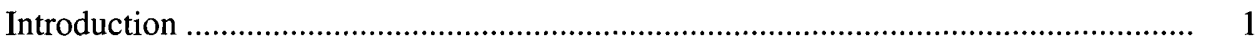

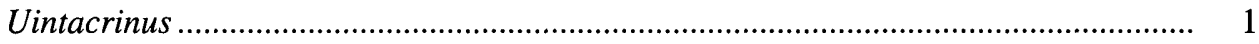

Marsupites ............................................................................................................. 3

USGS Localities at Which Uintacrinus or Marsupites Were Collected ....................... 3

Stratigraphic and Geographic Distribution of Uintacrinus socialis .............................. 4

References Cited .................................................................................................. 5

\section{FIGURES}

1. Map showing localities of Uintacrinus socialis Grinnell................................................................................. C2

2. Photograph showing Uintacrinus socialis Grinnell ....................................................................................... 3

3. Drawings showing Marsupites americanus Springer................................................................................... 3 


\title{
Occurrences of the Free-Swimming Upper Cretaceous Crinoids Uintacrinus and Marsupites in the Western Interior of the United States
}

\author{
By William A. Cobban
}

\begin{abstract}
The crinoids Uintacrinus Grinnell, 1876, and Marsupites Miller, 1821, are known from many localities in the world in rocks chiefly of late Santonian age. Specimens have been found at 12 localities in Montana, Wyoming, Utah, Colorado, and Kansas. Uintacrinus, represented by U. socialis Grinnell, 1876, is the most abundant species in the Western Interior. Marsupites, which is a little younger than Uintacrinus in the United States, is known from only a few fragments from the upper Santonian at two or three localities in Montana and Wyoming.
\end{abstract}

\section{INTRODUCTION}

The free-swimming crinoid Uintacrinus Grinnell (1876) was originally described from a specimen collected by O.C. Marsh (1871, p. 195) from rocks now assigned to the Mancos Shale south of the Uinta Mountains in northeastern Utah (fig. 1, X near Vernal), as well as from specimens from the Niobrara Formation of Kansas. The genus has long been considered as a guide fossil to rocks of late Santonian age (see, for example, Jeletzky, 1955, fig. 1; Ernst, 1963, table 4; Rawson and others, 1978, p. 27, table 2). In earlier reports (see, for example, Wegner, 1905, p. 125, 146; Heinz, 1928, pl. 3; Stolley, 1930, p. 189), mainly on the Cretaceous rocks of northwestern Germany and adjacent areas, two zones of free-swimming crinoids were recognized in that part of the Unter-Senon now referred to as the Santonian. Uintacrinus was shown as the older zone and Marsupites as the younger zone. Marsupites was originally described from the White Chalk of England (Miller, 1821, p. 135; Mantell, 1822, p. 183). The extinction of Marsupites has traditionally been used to mark the Santonian-Campanian boundary (for example, de Grossouvre, 1901, table 35; Muller and Schenck, 1943, fig. 6; Ernst, 1963, p. 107, table 4; Pechersky and others, 1983, p. 254; Schulz and others, 1983a, p. 85, table 2; 1983b, p. 185; Birkelund and others, 1984, p. 15; Hancock, 1991, p. 278). Voigt (1955), Bailey and others (1983b, p. 36, fig. 2), and Schulz and others (1984, fig. 1) showed that Uintacrinus overlaps the lower range of Marsupites, and Bailey and others (1983a, p. 11; 1983b, fig. 1; 1984, p. 37) noted that the species Uintacrinus anglicus Rasmussen succeeds Marsupites in England. According to this occurrence, Bailey and others $(1984$, p. 37) proposed that the top of the Santonian be placed at the top of the ranges of Uintacrinus and Marsupites "which appear to characterize the late Santonian worldwide."

From detailed investigations of the echinoids, crinoids, inoceramids, and belemnites, Ernst and others (1979, fig. 11) showed the following zonation for the Santonian Stage in northwestern Germany.

$$
\begin{array}{ll}
\text { Upper Santonian } & \left\{\begin{array}{l}
\text { Marsupites testudinarium/Gonioteuthis granulata } \\
\text { Uintacrinuswestfalicus/Gonioteuthis granulata }
\end{array}\right. \\
\text { Middle Santonian } & \left\{\begin{array}{l}
\text { Gonioteuthis westfalicagranulata } \\
\text { Inoceramus cordiformis/Gonioteuthis westfalica }
\end{array}\right. \\
\text { Lower Santonian }\left\{\begin{array}{l}
\text { Inoceramus undulatoplicatus }
\end{array}\right.
\end{array}
$$

The European Uintacrinus westphalicus Schlüter (1878) closely resembles the American $U$. socialis Grinnell (1876), as pointed out by Clark (1893, p. 24). As a result of an extensive study, Springer (1901, p. 87) concluded that the European and American forms represented one species, $U$. socialis.

\section{UINTACRINUS}

Uintacrinus Grinnell (1876) was named for a specimen from the Mancos Shale on Brush Creek near Vernal, Utah, and the species $U$. socialis Grinnell (1876) was based on specimens from the Niobrara Formation of central western Kansas. The Kansas specimens suggest that the species was gregarious and lived in swarms, hence, the origin of Grinnell's species name. Collections made later in Kansas included spectacular thin slabs of limestone covered by numerous well-preserved specimens. Springer $(1901$, p. 4) described a slab that "was approximately fifty feet long on the outcrop, and extended into the hill for a maximum 


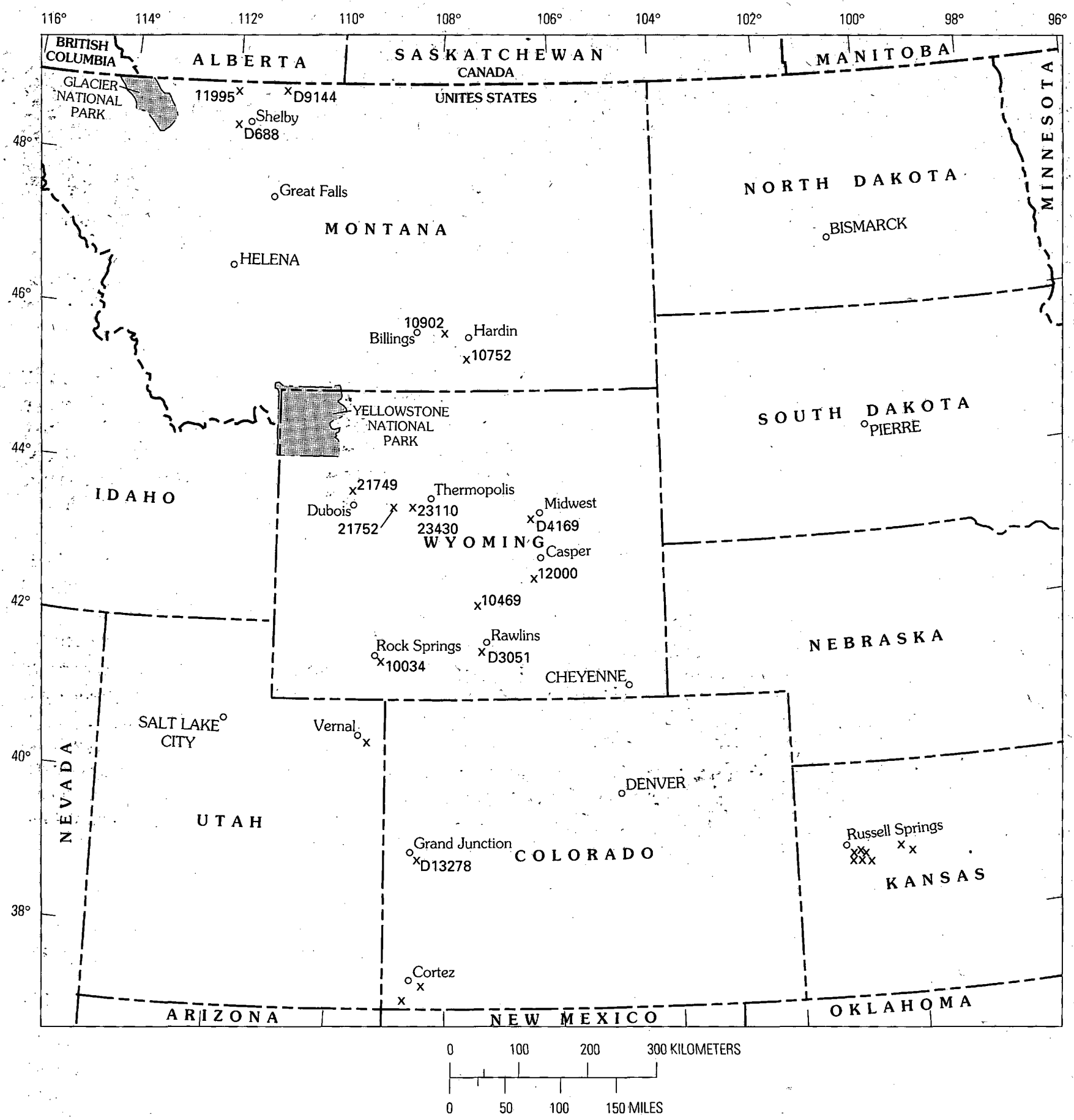

Figure 1. Map of part of the Westerni Interior of the United States showing localities of Uintacrinus socialis Grinnell (x's); USGS localities are numbered. Stratigraphic positions of collections are given in text.

distance of about twenty feet." Some 1,200 crinoid specimens were obtained from this slab. Schuchert (1904) illustrated part of this slab, which is now at the U.S. National Museum of Natural History, Washington, D.C. This part, almost 1.5 by $1.5 \mathrm{~m}$, has about 140 specimens. Beecher $(1900$, pls. 3,4$)$ illustrated a slab about 1.3 by $2.0 \mathrm{~m}$ in the Yale University Museum that contains 220 specimens of
U. socialis. Other slabs have been illustrated by Meek (1876, figs. A, B), Logan (1898, pls. 112, 113), Bassler (1909, pls. 17, 18), Miller and others (1957, fig. 1), Miller (1968, pl. 9 , fig. 5), and Hattin (1982, pl. 9, fig. 2), as well as in some textbooks on geology (see, for example, Moore, 1958, fig. 16.15). Part of a slab was featured on the cover of a recent issue of Science (v. 253, no. 5021, August 1991). Part of a 


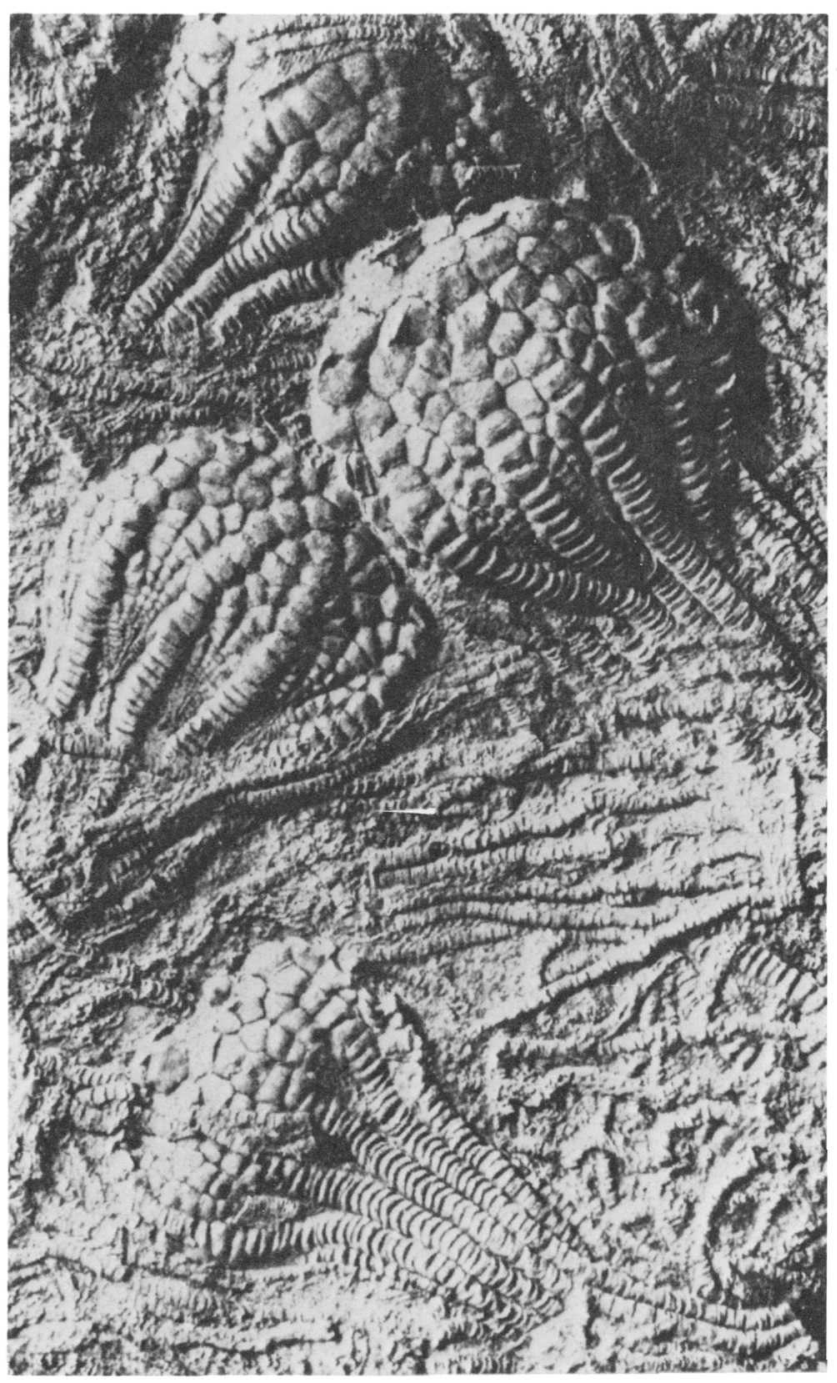

Figure 2. Uintacrinus socialis Grinnell on part of a slab of limestone from the Smoky Hill Chalk Member of the Niobrara Formation of central-western Kansas illustrated by Logan (1898, pl. 113). Natural size. By permission of the Kansas Geological Survey.

slab figured by Logan (1898, pl. 112) is illustrated herein (fig. 2). In all of these slabs, specimens of $U$. socialis are entangled with one another by their arms and pinnules. The arms are lengthy, and Springer (1901, p. 15) measured one arm $100 \mathrm{~cm}$ long that came from a calyx of $62 \mathrm{~mm}$ diameter.

Uintacrinus socialis was monographed by Springer (1901). Other important observations were made by Meek (1876), Clark (1893), Hill (in Williston, 1894), Bather (1896), Springer (1900), Bassler (1909), and Clark and Twitchell (1915). The origin of Uintacrinus is unknown, and Bather (1896, p. 974) long ago noted "it is a forlorn foundling, with not even a birth-mark to reveal its parentage."

Uintacrinus socialis has been recorded from Europe, where it is usually regarded as a zonal fossil of the lower part of the upper Santonian, although Hancock (1989, fig. 7) considered it as middle Santonian. The species is known from
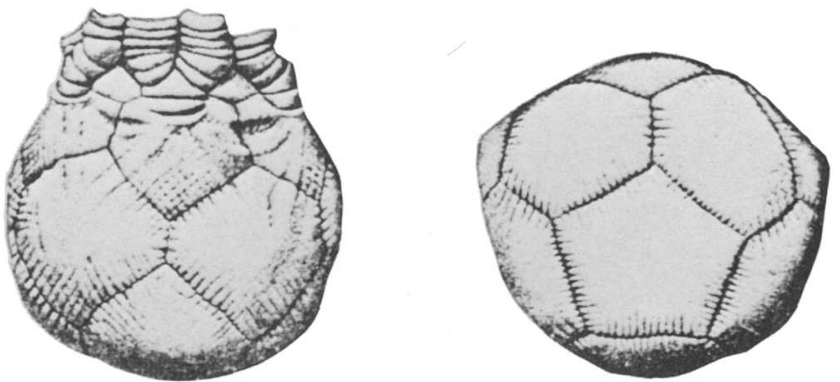

Figure 3. Side $(A)$ and basal $(B)$ views of Marsupites americanus Springer illustrated by Clark and Twitchell (1915, pl. 7). Natural size.

the British Isles (Brydone, 1932; Rawson and others, 1978, p. 27, table 4; Bailey and others, 1983b, figs. 1,2), Germany (Schulz and others, 1983a, table 2; 1984, p. 206, figs. 1, 4), and Russia (Klikushin, 1983, p. 103; Naidin and others, 1984 , p. 4). Rasmussen (1961, p. 404) recorded it also from France, Italy, and Australia.

\section{MARSUPITES}

Marsupites (Miller, 1821, p. 134) is characterized by the 16 large plates of the calyx, which may be smooth or ornamented by radial ridges (fig. 3). The type species, $M$. milleri Mantell (1822, p. 184, pl. 16, figs. 6-9, 13-15), is from the White Chalk of England. The only species described from North America is M. americanus Springer (1911, p. 158, pl. 6, figs. 4a, b, 5) from the upper Santonian Tombigbee Sand Member of the Eutaw Formation at Plymouth Bluff, Mississippi.

\section{USGS LOCALITIES AT WHICH UINTACRINUS OR MARSUPITES WERE COLLECTED}

Uintacrinus socialis is present in 12 collections (fig. 1) of the U.S. Geological Survey (USGS). The USGS Mesozoic locality number, collectors, year of collection, locality, and stratigraphic position are as follows (prefix D indicates Denver Mesozoic locality numbers; the rest are Washington, D.C., Mesozoic locality numbers):

D688 C.E. Erdmann, 1955. NW 1/4NE 1/4 sec. 31, T. 32 N., R. 3 W., Toole County, Mont. Marias River Shale, $1.5 \mathrm{~m}$ below top.

D3051 J.H. Smith, 1961. NW 1/4 sec. 26, T. 19 N., R. 88 W., Carbon County, Wyo. Steele Shale, $71.6 \mathrm{~m}$ above base.

D4169 J.H. Gill and R. Vaughn, 1962. NE1/4NW1/4 sec. 13, T. 39 N., R. 81 W., Natrona County, Wyo. Cody Shale, from Niobrara Member. 
D9144 E.A. Merewether, 1974. SW $1 / 4 \mathrm{SW}^{1 / 4}$ sec. 7, T. 36 N., R. 6 E., Liberty County, Mont. Marias River Shale, from upper part of Kevin Member.

D13278 W.A. Cobban, 1992. SW $1 / 4$ SW $1 / 4$ sec. 22, T. 2 S., R. 2 E., Mesa County, Colo. Mancos Shale, from Niobrara Member.

10034 C.J. Hares, 1917. Sec. 18, T. 18 N., R. 102 W., Sweetwater County, Wyo. Baxter Shale.

10469 A.E. Fath, 1920. NE 1/4 sec. 4, T. 25 N., R. 88 W., Carbon County, Wyo. Steele Shale.

10752 T.W. Stanton and W.T. Thom, Jr., 1921. Sec. 27, T. 4 S., R. 33 E., Big Horn County, Mont. About top of Telegraph Creek Formation.

10902 W.T. Thom, Jr., 1921. Sec. 27, T. 4 S., R. 3 W., Big Horn County, Mont. Base of Telegraph Creek Formation.

11995 A.J. Collier, 1923. Sec. 17, T. 35 N., R. 3 W., Toole County, Mont. Marias River Shale, within $6 \mathrm{~m}$ of top of Kevin Member.

12000 A.J. Collier, 1922. Sec. 18, T. 30 N., R. 80 W., Natrona County, Wyo. Niobrara Member of Cody Shale.

21749 R.M. Thompson, 1949. Horse Creek area north of Dubois, Fremont County, Wyo. Cody Shale.

21752 J.B. Reeside, Jr., and others, 1949. Northeast flank of Maverick Springs anticline in T. 6 N., R. 1 W., Fremont County, Wyo. Cody Shale, upper sandy part.

23110 M.L. Troyer, W.R. Keefer, and R. Burnside, 1950. SE $1 / 4$ NE $1 / 4$ sec. 23 , T. 6 N., R. 2 E., Fremont County, Wyo. Cody Shale, $744 \mathrm{~m}$ above base.

23430 W.A. Cobban, 1951. SW $1 / 4$ sec. 11, T. 6 N., R. 2 E., Fremont County, Wyo. Top of Cody Shale.

\section{STRATIGRAPHIC AND GEOGRAPHIC DISTRIBUTION OF UINTACRINUS SOCIALIS}

Uintacrinus socialis seems to be confined in the Western Interior to the upper Santonian zones of Desmoscaphites erdmanni and D. bassleri (Cobban, 1962, p. D140). The lower zone, D. erdmanni, is best developed in the uppermost part of the Kevin Member of the Marias River Shale in north-central Montana (fig. 1, locs. D688, D9144, 11995), where Collier (1929, p. 72) recorded the crinoid. Important molluscan fossils found in this zone in this part of Montana include Sphenoceramus lundbreckensis (McLearn), Baculites thomi Reeside, Clioscaphites novimexicanus (Reeside), an early form of Haresiceras (Mancosiceras) mancosense (Reeside), and the earliest form of Scaphites leei Reeside ( $S$. leei I). The upper zone, Desmoscaphites bassleri, is best developed in the Telegraph Creek Formation in south-central Montana (fig. 1, locs. 10752, 10902), where Thom and others $(1935$, p. 54, 55) recorded Uintacrinus and Marsupites with D. bassleri and a late form of Haresiceras (Mancosiceras) mancosense. A collection of D. bassleri from this part of Montana contains Sphenoceramus lundbreckensis, Baculites haresi Reeside, a late form of Haresiceras (Mancosiceras) mancosense, and Scaphites leei II.

Uintacrinus and Marsupites are present in Wyoming. Keefer and Troyer $(1956 ; 1964$, p. 88) found these crinoids in the upper part (sandy member) of the Cody Shale southwest of Thermopolis (fig. 1, locs. 23110, 23430). Associated fossils include Desmoscaphites bassleri, Scaphites leei II, and Haresiceras (Mancosiceras) mancosense. Uintacrinus socialis has also been found in the Cody Shale farther to the west near Dubois (fig. 1, loc. 21749). Near Midwest in east-central Wyoming (fig. 1, loc. D4169), U. socialis is present in the Niobrara Member of the Cody Shale associated with Sphenoceramus lundbreckensis. In the Rawlins area (fig. 1), U. socialis was found near the base of the Steele Shale along with Baculites thomi and $D$. bassleri at locality D3051 and in the Steele Shale at locality 10469. Farther west, near Rock Springs, $U$. socialis was found in the Baxter Shale at locality 10034.

A spectacular find of a slab of limestone covered by Uintacrinus socialis was recently made in the Mancos Shale near Grand Junction in western Colorado (fig. 1). The species has also been recorded from the Mancos Shale in the southwestern corner of Colorado (Pike, 1947, p. 43, table 1). Pike listed Desmoscaphites bassleri, Scaphites hippocrepis (DeKay), and Baculites asper Morton along with the crinoid. The S. hippocrepis is more likely $S$. leei, and the B. asper is probably B. thomi.

Occurrences of Uintacrinus socialis in western Kansas are clustered in the area southeast and east of Russell Springs (fig. 1), where the species was apparently found near the middle of the Smoky Hill Chalk Member of the Niobrara Formation (Hattin, 1982, p. 18). Although Hattin failed to find any specimens in the course of his detailed field studies, he believed that the finds made by earlier collectors were probably from the zone of Clioscaphites choteauensis, which is next below that of Desmoscaphites erdmanni in the Western Interior. Miller $(1968$, p. 8, 9) also believed that $U$. socialis occurred in the $C$. choteauensis zone, as well as even below the next older zone of $C$. vermiformis. Such stratigraphically low occurrences are unknown in other parts of the Western Interior.

Marsupites has been reported from only two localities in the Western Interior. Thom and others (1935, p. 55) reported Marsupites sp. (identified by F. Springer) from USGS Mesozoic locality 10752 in sec. 27, T. 4 S., R. 33 E., Big Horn County, Mont. (fig. 1). The specimen was found at the top of the Telegraph Creek Formation, whereas Uintacrinus was found at the base of the formation in sec. 27, T. $1 \mathrm{~S}$., R. 30 E. (fig. 2, loc. 10902). Desmoscaphites bassleri was 
reported with the crinoids at both localities. The sequence of Marsupites above Uintacrinus is typical of most European records. The other records of Marsupites in the Western Interior are those of Keefer and Troyer $(195 ; 6 ; 1964$, p. 88), who listed Marsupites sp. and Uintacrinus $\mathrm{sp}$. with D. bassleri and Scaphites leei from the upper part of the Cody Shale in west-central Wyoming (fig. 1, loc. 23430). The collection from that locality consists of the comminuted remains of one or more specimens of a species of Marsupites characterized by dominantly smooth calyx plates much like those of $M$. milleri Mantell. Parts of the arms associated with these plates were interpreted as from Uintacrinus, but they are more likely from Marsupites. Fragments of crinoid arms scattered in sandstone in the upper part of the Cody Shale at a locality farther to the west (fig. 1, loc. 21752) are probably from Marsupites. Associated ammonitès include Baculites thomi, Desmoscaphites bassleri, and Scaphites leei.

\section{REFERENCES CITED}

Bailey, H., Gale, A., Mortimore, R., Swiecicki, A., and Wood, C., 1983a, Criteria for defining the Coniacian to Maastrichtian stage boundaries in England [abs.], in Symposium on Cretaceous Stage Boundaries, Copenhagen, 1983: International Union of Geological Sciences, Subcommission on Cretaceous Stratigraphy, p. 9-12.

1983b, The Coniacian-Maastrichtian stages of the United Kingdom, with particular reference to southern England: Newsletters on Stratigraphy, v. 12, no. 1, p. 29-42.

Bailey, H.W., Gale, A.S., Mortimore, R.N., Swiecicki, A., and Wood, C.J., 1984, Biostratigraphical criteria for the recognition of the Coniacian to Maastrichtian stage boundaries in the Chalk of north-west Europe, with particular reference to southern England: Bulletin of the Geological Society of Denmark, v. 33, pt. 1-2, p. 31-39.

Bassler, R.S., 1909, Some noteworthy accessions to the Division of Invertebrate Paleontology in the National Museum: Smithsonian Miscellaneous Collections, v. 52, p. 267-269.

Bather, F.A., 1896, On Uintacrinus; a morphological study: Proceedings of the Zoological Society of London for 1895, p. 974-1003.

Beecher, C.E., 1900, On a large slab of Uintacrinus from Kansas: American Journal of Science, v. 159, p. 267, 268.

Birkelund, T., Hancock, J.M., Hart, M.B., Rawson, P.F., Remane, J., Robaszynski, F., Schmid, F., and Surlyk, F., 1984, Cretaceous stage boundaries-Proposals: Geological Society of Denmark Bulletin, v. 33, pt. 1-2, p. 3-20.

Brydone, R.M., 1932, The course of Marsupites and Uintacrinus across Norfolk: Transactions of the Norfolk and Norwich Naturalists' Society, v. 13, pt. 2, p. $115 \div 118$.

Clark, W.B., 1893, The Mesozoic Echinodermata of the United States: U.S. Geological Survey Bulletin 97, 207 p.

Clark, W.B., and Twitchell, M.W., 1915, The Mesozoic and Cenozoic Echinodermata of the United States: U.S. Geological Survey Monograph 54, $341 \mathrm{p}$.

Cobban, W.A., 1962, Late Cretaceous Desmóscaphites Range Zone in the Western Interior region, in Geological Survey Research
1962: U.S. Geological Survey Professional Paper 450-D, p. D140-D144.

Collier, A.J., 1929 [1930], The Kevin-Sunburst oil field and other possibilities of oil and gas in the Sweetgrass arch, Montana: U.S. Geological Survey Bulletin 812-B, p. 57-189.

Ernst, G., 1963, Stratigraphische und gesteinschemische Untersuchungen im Santon und Campan von Lägerdorf (SW-Holstein): Mitteilungen aus dem Geologischen Staatsinstitut in Hamburg, no. 32, p. 71-127.

Ernst, G., Schmid, F., and Klischies, G., 1979, Multistratigraphische Untersuchungen in der Oberkreide des Raumes Braunschweig-Hannover: International Union of Geological Sciences, ser. A., no. 6, p. 11-46.

Grinnell, G.B., 1876, On a new crinoid from the Cretaceous formation of the West: American Journal of Science, 3rd ser., v. 12, p. 81-83.

Grossouvre, A. de, 1901, Recherches sur la craie supérieur, part 1, no. 2, Stratigraphie générale; Mémoires pour servir à l'explication la carte géologique détaillée de la France: Paris, Imprimerie Nationale, p. 561-1013.

Hancock, J.M., 1989, Sea-level changes in the British region during the Late Cretaceous: Proceedings of the Geological Association [London], v. 100, pt. 4, p. 565-594.

1991, Ammonite scales for the Cretaceous System: Cretaceous Research, v. 12, p. 259-291.

Hattin, D.E., 1982, Stratigraphy and depositional environment of Smoky Hill Chalk Member, Niobrara Chalk (Upper Cretaceous) of the type area, western Kansas: Kansas Geological Survey Bulletin 225, $108 \mathrm{p}$.

Heinz, R., 1928, Das Inoceramen-Profil der Oberen Kreide Lüneburgs mit Anführung der neuen Formen und deren Kennzeichnung: Jahresbericht des Niedersächsischen geologischen Vereins zu Hannover, 21st, p. 63-81.

Jeletzky, J.A., 1955, Evolution of Santonian and Campanian Belemnitella and paleontological systematics; exemplified by Belemnitella praecursor Stolley: Journal of Paleontology, v. 29 , no. 3, p. 478-509.

Keefer, W.R., and Troyer, M.L., 1956, Stratigraphy of the Upper Cretaceous and lower Tertiary rocks of the Shotgun Butte area, Fremont County, Wyoming: U.S. Geological Survey Oil and Gas Investigations Chart OC-56.

1964, Geology of the Shotgun Butte area, Fremont County, Wyoming: U.S. Geological Survey Bulletin 1157, 123 p.

Klikushin, V.G., 1983, Distribution of crinoidal remains in the Upper Cretaceous of the U.S.S.R.: Cretaceous Research, v. 4, p. $101-106$.

Logan, W.N., 1898, The invertebrates of the Benton, Niobrara, and Fort Pierre Groups: Kansas University Geological Survey, v. 4, pt. 8 , p. $431-518$.

Mantell, G., 1822, The fossils of the South Downs, or illustrations of the geology of Sussex: London, Lupton Relfe, $327 \mathrm{p}$.

Marsh, O.C., 1871, On the geology of the eastern Uintah Mountains: American Journal of Science, 3rd ser., v. 1, no. 3, p. 191-198.

Meek, F.B., 1876, Note on the new genus Uintacrinus Grinnell: U.S. Geological and Geographical Survey of the Territories Bulletin, v. 2, p. 375-378.

Miller, H.W., 1968, Invertebrate fauna and environment of deposition of the Niobrara Formation (Cretaceous) of Kansas: Fort Hays Studies, new series, Science Series, no. 8, 90 p. 
Miller, H.W., Sternberg, G.F., and Walker, M.V., 1957, Uintacrinus localities in the Niobrara Formation of Kansas: Transactions of the Kansas Academy of Science, v. 60, no. 2, p. $163-166$.

Miller, J.S., 1821, A natural history of the Crinoidea or lily-shaped animals; with observations on the genera Asteria, Euryale, Comatula, and Marsupites, illustrated with fifty coloured plates: Bristol, C. Frost, 150 p.

Moore, R.C., 1958, Introduction to historical geology (2d ed.): New York, McGraw-Hill, $656 \mathrm{p}$.

Muller, S.W., and Schenck, H.G., 1943, Standard of Cretaceous System: American Association of Petroleum Geologists Bulletin, v. 27, no. 3, p. 262-278.

Naidin, D.P., Ben'yamovskii, V.N., and Kopaevich, L.F., 1984, Biostratigraphic classification of the Upper Cretaceous of the European paleobiogeographic region: Moscow University Geology Bulletin, v. 39, no. 5, p. 3-15.

Pechersky, D.M., Naidin, D.P., and Molostovsky, E.A., 1983, The Santonian-Campanian reversed polarity magnetozone and the Late Cretaceous magnetostratigraphical time-scale: Cretaceous Research, v. 4, p. 251-257.

Pike, W.S., Jr., 1947, Intertonguing marine and nonmarine Upper Cretaceous deposits of New Mexico, Arizona, and southwestern Colorado: Geological Society of America Memoir 24, 103 p.

Rasmussen, H.W., 1961, A monograph on the Cretaceous Crinoidea: Biologiske Skrifter udgivet uf det Kongelige Danske Videnskabernes Selskab, v. 12, no. 1, 428 p.

Rawson, P.F., and others, 1978, A correlation of Cretaceous rocks in the British Isles: Geological Society of London Special Report 9, $70 \mathrm{p}$.

Schlüter, C., 1878, Ueber einige astylide Crinoiden: Zeitschrift der Deutschen Geologischen Gesellschaft, v. 30, p. 28-66.

Schuchert, C., 1904, A noteworthy crinoid: Smithsonian Miscellaneous Collections, v. 45, p. 450.

Schulz, M.-G., Ernst, G., Ernst, H., and Schmid, F., 1984, Coniacian to Maastrichtian stage boundaries in the standard section for the Upper Cretaceous White Chalk of NW Germany (Lägerdorf-Kronsmoor-Hemmoor); definitions and proposals: Bulletin of the Geological Society of Denmark, v. 33, pt. 12, p. 203-215.

Schulz, M.G., Ernst, H., Schmid, F., and Ernst, G., 1983a, Séquence standard pour la craie du Crétacé supérieur de l'Allemagne du Nord-Ouest (Coniacien à Maastrichtien de Lägerdorf-Kronsmoor-Hemmoor): Géologie Méditerranéenne, v. 10 , no. $3-4$, p. $83-86$.

1983b, Standard section for the Upper Cretaceous White Chalk of NW Germany (Coniacian to Maastrichtian at Lägerdorf-Kronsmoor-Hemmoor): International Geological Correlation Programme, Symposium on Cretaceous Stage Boundaries, Copenhagen, 1983, p. 182-185.

Springer, F., 1900, Further note on Uintacrinus: American Geologist, v. 26, p. 194.

1901, Uintacrinus; its structure and relations: Harvard College Memoirs of Comparative Zoology, v. 25, no. 1, 89 p.

1911, Some new American fossil crinoids: Memoirs of the Museum of Comparative Zoology, no. 25, p. 117-161.

Stolley, E., 1930, Einige Bemerkungen über die Kreide Südskandinaviens: Geologiska Föreningens i Stockholm Förhandlingar, v. 52 , no. 2 , p. $157-190$.

Thom, W.T., Jr., Hall, G.M., Wegemann, C.H., and Moulton, G.F., 1935, Geology of Big Horn County and the Crow Indian Reservation, Montana: U.S. Geological Survey Bulletin 856, 200 p.

Voigt, E. 1955, Nachweis des Uintacrinus-Horizonte in der Kreide Schleswig-Holsteins: Neues Jahrbuch für Geologie und Paläontologie Monatshefte Jahrgang 1954, p. 224-228.

Wegner, T., 1905, Die Granulatenkreide des westlichen Münsterlandes: Zeitschrift der Geologischen Gesellschaft, v. 57, p. 112-232.

Williston, S.W., 1894, Notes on Uintacrinus socialis Grinnell: Kansas University Quarterly, v. 3, no. 1, p. 19-21. 